\title{
"The Fruit of the Poisonous Tree" Revisited and Shepardized
}

\author{
Robert M. Pitler*
}

\begin{abstract}
It is one of the misfortunes of the law that ideas become encysted in phrases and thereafter for a long time cease to provoke further analysis. ${ }^{1}$-Justice Oliver Wendell Holmes
\end{abstract}

$\mathrm{T}$ HE CHARACTERIZATION OF SECONDARY EVIDENCE which owes its discovery to evidence initially obtained in violation of a constitutional, statutory, or court-made rule as the "fruit of the poisonous tree"2 evokes more passion than rational analysis. Although the author is tempted to use a more neutral vocabulary, clarity and tradition require continued adherence to the established terminology.

The initially seized evidence customarily represents the "poisonous tree," but that evidence is itself the first generation fruit of some illicit governmental activity. Thus, the books and records seized in Weeks $v$. United States ${ }^{3}$ were the first generation fruit of an unlawful search and seizure. They were excluded because:

If letters and private documents can thus be seized and held and used in evidence against a citizen accused of an offense, the protection of the Fourth Amendment declaring his right to be secure against such searches and seizures is of no value, and, so far as those placed are concerned, might as well be stricken from the Constitution. ${ }^{4}$

Of course, there must be a significant relationship ${ }^{5}$ between the unlawful activity and the evidence seized to warrant exclusion. Hence, although the Weeks opinion is silent on causation, it is evident that there was a causal relationship between the illegal search and seizure and the documentary evidence which it uncovered.

*IL.B., 1966, Brooklyn Law School; LI.M., 1967, University of Michigan; Assistant Professor of Law at the University of Colorado Law School commencing in the fall of 1968. The author is extremely indebted to Professor Yale Kamisar of the University of Michigan for his guidance, interest, and legal writings which have contributed greatly to this article. The author also wishes to acknowledge his appreciation to Professor Jerold Israel of the University of Michigan for his comments and criticisms concerning the substance and organization of the article.

1 Hyde v. United States, 225 U.S. 347, 391 (1912) (dissenting opinion).

2 The phrase was coined by Justice Frankfurter in Nardone v. United States, 308 U.S. 338,341 (1939).

3232 U.S. 383 (1914).

4 Id. at 393.

- Some courts express the relationship in terms of causal connection. See Note, 66 YarE L.J. 270, 282 (1956). Others consider the relationship to be one of essential connection. See, e.g., Rogers v. Superior Court, 46 Cal. 2d 3, 10-11, 291 P.2d 929, 933-34 (1955). 
Given the right to be secure within the privacy of one's home from unreasonable searches and seizures, to admit evidence obtained in violation of this right would be, in effect, to "grant the right but in reality to withhold its privilege and enjoyment." The exclusionary rule is therefore designed "to deter-to compel respect for the constitutional guaranty in the only effectively available way-by removing the incentive to disregard it." This rationale also underlies the exclusion of coerced

6 Mapp v. Ohio, 367 U.S. 643, 656 (1961). The holding in Wolf v. Colorado, 338 U.S. 25 (1949), that an illegal search and seizure by a state officer violates the fourteenth amendment, but that the fourth amendment's exclusionary rule is not incorporated by the fourteenth has been described as "simultaneously creating a constitutional right and denying the most effective remedy for the violation of that right." Perlman, Due Process and the Admissibility of Evidence, 64 HARV. L. REv. 1304 (1951).

7 Mapp v. Ohio, 367 U.S. 643, 656 (1961). See also Elkins v. United States, 364 U.S. 206, 217 (1960). Even before the Elkins and Mapp decisions one commentator wrote:

[I]t would seem that the ultimate test of the exclusionary rules is whether they deter police officials from engaging in the objectional practices. For if, as some assert, reversals of convictions in this area have had no substantial effect on pobice conduct, then the consequent gains even in terms of popular respect for law are tenuous indeed.

Allen, Due Process and State Criminal Procedures: Another Look, 48 Nw. U.L. REv. 16, 34 (1953).

In Mapp there is language to indicate there was another consideration-"the imperative of judicial integrity"-for excluding the evidence. Mapp v. Ohio, supra at 659, citing Elkins v. United States, supra at 222. "The criminal goes free, if he must, but it is the law that sets him free. Nothing can destroy a government more quickly than its failure to observe its own laws, or worse, its disregard of the charter of its own existence." Mapp v. Ohio, sthpra at 659. See also Berger v. New York, 388 U.S. 41 (1967) (Harlan, J., dissenting). The subsequent retroactivity decision of Linkletter v. Walker, 381 U.S. 618, 636-37 (1965), makes it clear, however, that the deterrence of illegal police conduct lies at the core of the exclusionary rule. See generally Note, 37 U. CHr. L. REv. 342, 352-59 (1967).

It is conceivable that evidence should be excluded regardless of the deterrent effect of such exclusion. Cf. Irvine v. California, 347 U.S. 128 (1954). (Frankfurter, J., dissenting); Rochin v. California, 342 U.S. 165 (1952). The oft-quoted statement of Mr. Justice Brandeis best illustrates the view that introduction of illegally obtained evidence breeds contempt for the law:

In a government of laws, existence of the government will be imperiled if it fails to observe the law scrupulously. Our government is the potent, the omnipresent teacher. For good or for ill, it teaches the whole people by its example. Crime is contagious. If the Government becomes a lawbreaker, it breeds contempt for law; it invites every man to becone a law unto himself; it invites anarchy. To declare that in the administration of the criminal law the end justifies the means-to declare that the Government may commit crimes in order to secure the conviction of a private criminal-would bring terrible retribution. Against that pernicious doctrine this Court should resolutely set its face.

Olmstead v. United States, 277 U.S. 438, 485 (1928) (dissenting opimion). See also Hogan \& Snee, The McNabb-Mallory Rule: Its Rise, Rationale and Rescue, 47 Geo. L.J. 1, 29 (1958); Younger, Prosecution Problems, 53 A.B.A.J. 695, 696 (1967). For the different theories of exclusion see Comment, 57 CoLUM. L. REv. 1159, 1164-70 (1957) and material cited therein.

The deterrence rationale has been severely challenged by critics of the Court. See Inbau, Restrictions in the Law of Interrogation and Confessions, 52 NW. U.L. REv. 77, 78 (1957); 
confessions ${ }_{9}^{8}$ statements obtained during a period of unnecessary delay in bringing a suspect before a magistrate ${ }^{9}$ conversations overheard in violation of section 605 of the Federal Commumications Act, ${ }^{10}$ and conversations overheard through unlawful entries into constitutionally protected areas. ${ }^{11}$

In each of the above situations the government's failure to obey a constitutional, statutory, or judicial rule resulted in the exclusion of evidence significantly connected to the illegal activity. The evidence initially obtained by virtue of the illicit conduct becomes the "poisonous tree." When this evidence leads to other evidence, then the secondary evidence becomes the "fruit of the poisonous tree."

The difficult problem is to develop and apply standards designed to determine whether derivative evidence owes its discovery to some form of unlawful governmental activity - that is, whether the evidence in question is fruit of the poisonous tree. Following a brief introduction, this Article will focus on the exclusionary rule as apphed to the fruit of illegally obtained evidence, hopefully illuminating the complexities of the "fruit of the poisonous tree" doctrine.

\section{I}

GENERAI PRINCIPLES OF THE EXCLUSIONARX RULE

Before examining the exclusionary rule as applied to secondary evidence gleaned from illegally obtained primary evidence, it is instructive to assess the policies behind the exclusionary rule. An exclusionary rule may derive from a constitutional, statutory, or judicial source, and it is axiomatic that states are not precluded from enacting laws which provide

Peterson, Restrictions in the Law of Search and Seizure, 52 Nw. U.L. REv. 46, 56 (1957). It may be impossible to measure the effectiveness of the deterrence of such activity. See generally Kamisar, Public Safety v. Individual Liberties: Some "Facts" and "Theories," 53 J. CRnT. I.C. \& P.S. 171, 179-82 (1962).

The problem is that there is apparently no better or more effective way of enforcing constitutional limitations on the police. See Paulsen, The Exclusionary Rule and Misconduct by the Police, 52 J. CRIN. L.C. \& P.S. 255 (1961). Even the rule's critics concede the ineffectiveness of proposed alternatives. See McGarr, The Exchusionary Rule: An Ill Conceived and Ineffective Remedy, 52 J. CROM. L.C. \& P.S. 266, 268 (1961). However some suggest making the municipality which employs the policeman responsible for the illegal activity on the basis of respondeat superior. Cf. Plunib, Illegal Enforcement of the Law, 24 CorNenc I.Q. 337,387 (1939). Compare Peterson, supra, at 62 ; where the author suggests establishing an official guardian who would operate independently from the prosecutor and would investigate and prosecute constitutional violations; with Paulsen, supra, at 261. See also Gellhorn, The Swedish Justitieombudsman, 75 YALE I.J. 1 (1965); Hall, Police and Law in a Democratic Society, 28 IND. L.J. 133, 173-75 (1953).

${ }^{8}$ See Brown v. Mississippi, 297 U.S. 278, 285-86 (1936).

See Mallory v. United States, 354 U.S. 449,455 (1957).

10 Nardone v. United States, 302 U.S. 379 (1937).

11 Silverman v. United States, 365 U.S. 505 (1961). 
greater protection than that required by the Constitution. However, a state legislature in passing a law regulating police activity or a state court in interpreting it, may, within constitutional limitations, decide that certain or all violations sliould not give rise to the exclusion of reliable evidence.

It may, of course, be argued that rules regulating police conduct are valuable even without the sanction of the exclusionary rule. States commonly enact laws which are never enforced. Certain penal statutessodomy, fornication, adultery, and attempted suicide-are rarely the basis for criminal prosecutions. Nevertheless, one might persuasively argue that these statutes serve to discourage the prohibited conduct thereby performing a positive social function. ${ }^{12}$ If society is reassured or made niore comfortable with these laws on the books, one might well conclude that they are desirable and necessary.

A statute which proscribes certain police conduct miglit be found designed to perform the same function. A state legislature may desire to reassure certain segments of society that its civil hiberties are being lionored or to encourage law enforcement officials to restrain their activities, while at the same time finding it unnecessary to exclude reliable evidence.

However, a statute regulating police activity is usually enacted with the intent that it be obeyed. ${ }^{13}$ If evidence illegally seized may be used at trial, police are encouraged to violate the statute. "[F]oolisl consistency is the hobgoblin of little minds," 14 but it is not foolish to expect that when a statute is passed, the incentive to violate it slould also be removed. If a constitutional or statutory provision regulating police conduct is both desirable and necessary, should it not be made as effective as possible?

\section{A. Competing Standards for the Exclusionary Rule}

In interpreting a state statute regulating police activity, courts may determine that technical violations do not warrant the exclusion of reliable evidence. ${ }^{15}$ This position seems feasible in construing a state statute granting rights which are not constitutionally mandated. Law enforcement officials may make administrative errors which can be easily remedied. Further, by overseeing with particular care the administration of

12 "There are many things that are denounced by the Criminal Code that cannot be prosecuted with success. But it is important that they be denounced by the Criminal Code in order that society may know that the state disapproves." Judge Parker, 32 ALI ProcEEDINGS 128 (1955).

13 "Criminal law which is not enforced practically ... is much worse than if it was not on the books at all." Learned Hand, id. at 129.

14 Emerson, Self-reliance, in Essays 29, 37 (1906).

15 See State v. Grady, 153 Conn. 26, 28, 211 A.2d 674, 675 (1965). 
the statute, the highest court of the state could probably assure that a given error is, in fact, a technicality.

Persuasive arguments have been made for an exclusionary rule only for grave violations of a statute:

The more outrageous the violation, the stronger deterrent we need, and consequently the wider the sweep of the "fruits" doctrine should be. If, on the other hand, the rule violated stands low in our hierarchy of values, the argument that violation must be deterred at all costs is considerably less compelling. ${ }^{16}$

Such a rule calls for the exercise of discretion by the trial court. ${ }^{17}$ But, experience with the issuance of search warrants ${ }^{18}$ and the old "voluntariness" test ${ }^{10}$ in confession cases leads one to doubt whether lower court judges are the proper recipients of sucli discretion. Nevertheless, in a single jurisdiction sucli a rule may prove workable with careful review by appellate courts.

On the other hand, the "grave" violation standard involves a great deal of subjectivity on the part of judges, making it extremely difficult to draw any real lines of distinction. Unable to foresee what activity will result in the exclusion of evidence, law enforcement officials may find it difficult to establish workable rules of procedure and convenient not to take the proscription seriously.

A third possible standard might make admissibility turn on the "good faith" of the police officer. ${ }^{20}$ This test does not lend itself to adequate

10 Ali Model Code of Pre-Arraignaent Procedures 76 (1966) [hereinafter cited as MODEL CODE]. The Code is at this point speaking of statements of the accused but appears to make the discussion applicable to all violations of the Code. Another commentator suggests that the decision whether to exclude evidence (making no distinction between the fruit or the tree) should "be left to the discretion of the trial judge, to be exercised with regard to certain specific criteria. Among these would be the kind of illegality, the good faith of the police, the seriousness of the crime, and the prosecution's need for the evidence." Newman, Cops, Courts \& Congress: Is Citizen Safety Unconstitutional?, THE NEw RepubLIC, Mar. 18, 1967, at 16, 18. Such an approach was rejected by two of the reporters to the Model Code. $C f$. Bator and Vorenberg, Arrest, Detention, Interrogation and the Right to Counsel: Basic Problems and Possible Legislative Solutions, 66 Corom. L. Rev. 62, 76 (1966).

17 Judge Walter Schaefer has "come to believe that if enforcement of the rules of evidence were turned over on a broad scale to the discretion of trial judges, the rule to be applied would depend on the personality of the individual judge. . . Appellate court reversals would be reduced, but the even-handed administration of justice would be sacrificed." W. Schaefer, Tare SUSPECT AND Soctety 34 (1967); see note 16 supra.

18 The magistrate's function in issuing search warrants has been described "as a mere ministerial duty, with the real decision having been made in the office of the prosecutor." W. La Fave, Arrest: The Dectsion to Take a Suspect into Custody 33 (1965).

10 See Kamisar, A Dissent from the Miranda Dissents: Some Comments on the "New" Fifth Amendment and the Old "Voluntariness" Test, 65 MrCH. L. Rev. 59 (1966).

20 "[E]xclusion should surely not be demanded where the officer did not know and had no reason to know that in some minor technicality he was violating a rule." Bator and Vorenberg, supra note 14 , at 77 . 
review since the testimony and demeanor of the police officer could be reflected on appeal only by a "cold record." In addition, since it would be extremely difficult to prove that a police officer deliberately violated a statute, the "good faith" test could easily result in wholesale affirmance of statutory violations. Moreover, it seems fair to assume that typical police errors are honest mistakes by overzealous or undertrained police officers.

While the above approaches may be feasible when administering a state statute, ${ }^{21}$ federal statutes and the Federal Constitution present different problems. How are state courts to determine which constitutional violations are technical and which are grave? Which riglits are fundamental and which are not? ${ }^{22}$ What means are available to measure the "grave" against the "not so grave"? Is it not also possible to be confronted with a "mildly grave" violation? ${ }^{23}$

[A] distinction of the kind urged would leave the rule so indefinite that no state court could know what it should rule in order to keep its processes on solid constitutional grounds. ${ }^{24}$

Moreover, as Judge Schaefer points out, the Supreme Court when dealing with federal constitutional or statutory standards

will be searching for some automatic device by which the potential evils [of official illegality] can be controlled. Any technique by which its responsibility to guard against improper police conduct can be effectively delegated, with the assurance that the exercise of the delegated authority can be readily supervised is bound to be attractive to the Court.25

There is reason to believe that this idea contributed significantly to the replacement of the old "voluntariness" test in confession cases by the four-part warning of Miranda v. Arizona. ${ }^{26}$ However, as the Supreme Court continues to limit the scope of sophisticated and subtle as well as elementary and crude illegal police practices, resistance to an inexorable application of the "fruit of the poisonous tree" doctrine increases.

Surely if the "poisonous tree" doctrine were limited to confessions

21 See Traynor, Mapp v. Ohio at Large in the Fifty States, 1962 DUKE L.J. 319, 327.

22 See Allen, Federalism and the Fourth Amendment: A Requiem for Wolf, 1961 Sup. CT. Rev. $1,9$.

${ }^{23}$ See Kamisar, Wolf and Lustig Ten Years Later: Illegal State Evidence in State and Federal Courts, 43 ManN. L. Rev. 1083, 1123 (1959).

24 Irvine v. California, 347 U.S. 128, 134 (1954). Cf. Berger v. New York, 388 U.S. 41, 105-06 (Harlan, J., dissenting).

25 W. Schaefer, The Suspect and Socrety 10 (1967). See also Traynor, sitpra note 19, at 327 .

26384 U.S. 436, 476 (1966). 
extracted by rack and screw methods as it was decades ago, lower courts would have less trouble excluding derivative evidence than they do today. Miranda v. Arizona, ${ }^{27}$ which requires the police to give certain specific and detailed warnings to a suspect before questioning him, has evoked from some the expected outcry that, if the fruits of an inadmissible confession are excluded, "the impact on law enforcement will be disastrous." 28 However, a broad reading of "compel" within the meaning of that decision is based on the privilege against self-incrimination, not a sense of outrage or shock at the employment of "coercion" in its more primitive form. Miranda's basic appeal is to concepts of justice and equality $^{29}$ rather than to the conscience of commentators and judges. A confession obtained without the required warnings is just not as repellant or unconscionable as one obtained as a result of the "rack and screw."130 Thus, there is understandable reluctance to exclude the fruits of such a confession.

A different problem presents itself when a defendant, after he has confessed, is mistreated by the pohice. In light of our desire to prevent such conduct, might it not be a good idea to exclude the confession here, too? What if the suspect confesses and one of three officers begins to beat him before he can be restrained by the other officers? What if a search incident to an arrest uncovers incriminating evidence, the suspect is removed to the police station and confesses, and only then is "roughed up?" Is the evidence uncovered in the search to be excluded? What of evidence discovered after, but not the result of the suspect's mistreatment? The Supreme Court has rejected a "deterrence without causation" approach, requiring some degree of causation between the illicit conduct and the evidence sought to be introduced. ${ }^{31}$ The "pure deterrence" rule would be extremely difficult to administer on a national level, but might in some situations be the proper vehicle for a state court to control and discourage illicit police conduct. ${ }^{32}$

27384 U.S. 436 (1966).

28 See, e.g., George, Interrogation of Criminal Defendants-Some Views on Miranda v. Arizona, 35 FoRdHAar L. REV. 193 (1966). See also Lynch, Interrogation of Criminal Defendants-Some Views on Miranda v. Arizona, id. at 221, 277.

${ }^{20}$ See Edwards, Interrogation of Criminal Defendants-Some Views on Miranda v. Arizona, 35 ForderAM L. REv. 181, 181-92 (1966); Graham, What is "Custodial Interrogation"?: California's Anticipatory Application of Miranda v. Arizona, 14 U.C.L.A.I. REv. 59,64 (1966).

30 Cf. MOdex Code, supra note 16 , at 76.

31 See United States v. Mitchell, 322 U.S. 65 (1944); Goldman v. United States, 316 U.S. 129 (1942).

32 See Churn v. State, 184 Tenn. 646, 202 S.W.2d 345 (1947), where the court reversed a lower court decision by rejecting the testimony of two officers because they had beaten the defendant. The decision indicates that the beating was designed to procure an admission. 


\section{B. The Exclusionary Rule as a Deterrent to Illegal Police Activity}

It is, of course, incorrect to assume and too much to expect that the exclusionary rule will deter all illicit police activity. Often the police will act illegally for harassment purposes to prevent certain activities-gambling and prostitution, for example -or to satisfy the public's demand for action on vice-squad crimes. The threat of excluding evidence will, at least in these situations, be insignificant. Dean Francis Allen suggests that " $[t]$ he uncomfortable possibility even exists that the presence of the exclusionary rule in a jurisdiction may in certain situations influence the police to reject efforts to make a case for formal prosecution and to rely on such informal and illegal sanctions as they see fit to devise and apply."33

The same author, however, indicates that "in localities where police illegality is most deliberate and systematic, conviction of offenders remains obviously an important objective of police activity. One may assume that the presence of the rule induces a degree of caution and care in preparing the case that might otherwise be lacking. ${ }^{334}$ Althougl the exclusionary rule may not deter all official illegality, it is fair to assume that it is the most effective way of limiting such methods. ${ }^{35}$

\section{Exclusion of the Fruits of Illegally Obtained Evidence}

The complete exclusion-in all situations and for all purposes-of second and subsequent generation "fruits" of illegally obtained evidence seems logical and warranted unless there are competing considerations to restrict the radiations of the exclusionary rule. The obvious competing consideration, in criminal as well as civil cases, is the policy of admitting relevant and trustworthy evidence in order to maximize the search for truth. In criminal prosecutions the exclusionary rule conflicts with another interest of society-convicting the guilty. Hence, departures "from the primary evidentiary criteria of relevancy and trustworthiness must be justified by some strong social policy." ${ }^{136}$ Even Judge Skelly

${ }^{33}$ Allen, Federalism and the Fourth Amendment: A Requiem for Wolf, 1961 SUP. Cr. REv. 1, 39. The head of a federal narcotics unit is reported to have said that "his men do search unlawfully because they have an obligation to get narcotics off the street even if no prosecution results." J. Landynszi, Searce \& Seizure and tae Supreme Court 193 n.92 (1966). See also Graham, The Cop's Right(?) to Search and Frisk, N.Y. Times, Dec. 10, 1967, \& 6 (Magazine) at $44,153$.

34 Allen, supra note 33 , at 39 .

85 Even Professors Bator and Vorenberg, the principal draftsmen of the Model Code of Pre-Arraignment Procedures, who have viewed the Suprerne Court's restrictions on police practices with something less than enthusiasm, recognize the need to place primary reliance on an exclusionary rule as a sanction for illegal police activity. See Bator \& Vorenberg, supra note 16 , at 76 .

${ }^{86}$ On Lee v. United States, 343 U.S. 747, 755 (1952). See also Lopez v. United States, 
Wright, a vigorous supporter of a strong exclusionary rule, recognizes that "though harsh penalties [for illegal police activities] are appropriate ... we cannot ignore the public safety im our attempt to correct police wrongdoing. ${ }^{337}$ The policies of admitting relevant and reliable evidence and convicting the guilty create a shield to repel the exclusionary rule's radiations. This may well explain the continued vitality, if not the origin of, the standing requirement, ${ }^{38}$ the use of illegally obtained evidence for impeachment purposes ${ }^{39}$ the harmless error rule, ${ }^{40}$ the refusal of courts to go behind guilty pleas, ${ }^{41}$ and the "attenuation of the taint" doctrine."

As observed above, the purpose of the exclusionary rule is to deter illegal police activity. "As it serves this function," Professor Anthony Amsterdam finds the rule to be a "needed, but grudgingly taken, medicament; no more should be swallowed than is needed to combat the disease. Granted that so many criminals must go free as will deter the constables from blundering, pursuance of this policy of liberation beyond the confines of necessity inflicts gratuitous liarm on the public interest . . ."

The problem is to determine how far is necessary. Shields against the logical radiations of the exclusionary rule-for example, the standing

373 U.S. 427, 440 (1963); Hawkins v. United States, 358 U.S. 74, 81 (1958) (Stewart, J., concurring); People v. Cahan, 44 Cal. 2d 434, 442-43, 282 P.2d 905, 910 (1955).

87 Killough v. United States, 315 F.2d 241, 249 (D.C. Cir. 1962) (concurring opinion).

88 Jones v. United States, 362 U.S. 257 (1960). The Supreme Court in Massiah v. United States, 377 U.S. 201 (1964), practically issued an invitation to illegally obtain evidence for use against an individual who lacks standing to object to the illicit conduct. "All that we hold is that the defendant's own incriminating statements . . . could not constitutionally be used by the prosecution as evidence against him at his own trial." Id. at 207. See also Wong Sun v. United States, 371 U.S. 471 (1963). Contra, People v. Martin 45 Cal. 2d 755, 290 P.2d 855 (1955). See generally I. Halx and Y. Kammsar, Modern Crmminat Procedure 143-44 (1966). See text accompanying notes 348-52 infra.

39 Walder v. United States, 347 U.S. 62 (1954). See text accompanying notes 266-90 infra.

40 Chapman v. California, 386 U.S. 18 (1967). The problems with the harmless error rule are well illustrated by the Chief Justice of the Nevada supreme court who wrote: "The 'harmless error gamble' may be willingly encountered by a prosecutor bent on victory, if he believes the law of his state manifests appellate hberty in using harmless error to save a conviction." Thompson, Unconstitutional Search and Seizure and The Myth of Harmless Error, 42 Notre Dange LAw. 457, 462 (1967).

For the present the Supreme Court has decided, at least in the context of fourth amendment violations, to permit the state to affirm convictions where the error was harmless beyond a reasonable doubt. Chapman v. California, supra.

41 Kercheval v. United States, 274 U.S. 220, 223-24 (1927). This rule was very persuasively used as an argument in favor of the retroactivity of Escobedo v. Mlinois, 378 U.S. 428 (1964). Note, 64 MrCE. L. REv. 832, 851-52 (1965). For an argument urging the reconsideration of the rule see Kamisar, The Right to Counsel and the Fourteenth Amendment: A Dialogue on "The Most Pervasive Right" of an Accused, 30 U. CHI. L. REv. 1, 29-31 (1962). infra.

42 Wong Sun v. United States, 371 U.S. 471 (1963). See text accompanying notes 315-30

48 Amsterdam, Search, Seizure and Section 2255: A Comment, 112 U. PA. L. REv. 378, 389 (1964). 
requirement-may produce a dual evil while performing no positive function. If these shields are thick enough to filter out the deterrent force of the exclusionary rule, then the rule creates two evils instead of one-the exclusion of reliable evidence and illicit police activity. Professor Yale Kamisar has suggested that such a half-hearted exclusionary rule may be worse than none at all..$^{44}$

In most situations where evidence is excluded in order to deter unlawful police conduct, the defendant is not thereby granted immunity from prosecution. As long as the illegally obtained evidence is not used, the defendant may be prosecuted based on independently secured evidence. If it is necessary and socially desirable to deter official illegality then why not provide the severest sanction possible-immunity from prosecution-for victims of illicit police practices? Such immunity, however, sometimes permits an otherwise guilty man to go free. The answer to the problem cannot be given in terms of pure logic, but it is nevertheless logical. For although society seeks to deter illicit police practices, it does not wish to create an even greater evil. Exclusion of reliable evidence may be an evil but absolute immunity from prosecution is too high a price to pay to deter illegal police conduct. ${ }^{45}$

\section{The Current Supreme Court Formulation of the Rule}

Granting that primary evidence obtained through illegal police activity is inadmissible at trial, the question remains whether and to what extent fruits of that evidence are admissible. The Supreme Court has developed a rule relying on a deterrence-causation rationale by which to judge the admissibility of the fruits of illegally obtained evidence. This rule permits the lower courts to exercise their discretion to determine:

Whether, granting establishment of the primary illegality, the evidence to which instant object is being made has been come at by exploitation of that illegality or instead by means sufficiently distinguishable to be purged of the primary taint. ${ }^{46}$

Unfortunately, this formulation of the admissibility rule obfuscates the relevant question which should be asked. Granting that the police have in some manner utilized the primary evidence, the question should be

44 Kamisar, Illegal Searches or Seizures and Contemporaneous Incriminating Statements: A Dialogue on a Neglected Area of Criminal Procedure, 1961 U. Irr. L. For. 78, 105.

45 "It is one thing to say that officers shall gain no advantage from violating the individual's rights; it is quite another to declare that such a violation shall put him beyond the law's reach even if his guilt can be proved by evidence that has been obtained lawfully." Sutton v. Umited States, 267 F.2d 271, 272 (4th Cir. 1959) (Sobeloff, C.J.). But cf. State v. Cory, 62 Wash. 2d 371, 382 P.2d 1019 (1963).

${ }^{46}$ Wong Sun v. United States, 371 U.S. 471, 488 (1963). 
whether the admission of this secondary evidence will significantly encourage illicit police conduct in the future.

The remainder of this Article will examine the "fruit of the poisonous tree" doctrine and locate where the policies favoring the admissibility of reliable evidence operate to create a shield agamst the logical extreme of exclusion. In each situation to be examined there will be some connection between initial police illegahty and the evidence sought to be suppressed. By what standard are we to judge the effect of the initial illegality on subsequent fruits? In short, is the purpose of the exclusionary rule to deter official illegality sufficiently served by excluding only the direct or first generation evidence, or does a sound deterrence policy proscribe all use of the "poisonous tree?"

II

HISTORY OF THE FRUIT OF THE POISONOUS TREE DOCTRINE

\section{A. Early Development}

The "fruit of the poisonous tree" doctrine was first enunciated in Silverthorne Lumber Company v. United States, ${ }^{47}$ where federal agents seized books, papers, and documents illegally and then plotographed the necessary information before returning the originals. Since Weeks $v$. United States ${ }^{48}$ had established that evidence seized in violation of the fourth amendment could not be introduced at trial, ${ }^{49} \mathrm{Mr}$. Justice Holmes, speaking for the Court, reasoned that to permit the Government to benefit from illegally seized evidence "reduces the Fourth Amendment to a form of words." ${ }^{.50}$ The genesis of the poisonous tree doctrine was then advanced:

The essence of a provision forbidding the acquisition of evidence in a certain way is that not merely evidence so acquired shall not be used before the Court but that it shall not be used at all. Of course this does not mean that the facts thus obtained become sacred and inaccessible. If knowledge of them is gained from an independent source they may be proved like any others, but the knowledge gained by the Government's own wrong cannot be used by it in the way proposed.51

A broad reading of Silverthorne leads to the conclusion that illegally seized evidence may never be used by the Government although the facts revealed by that evidence may be obtained from an independent source.

47251 U.S. 385 (1920).

48232 U.S. 383 (1910).

49 An examination of Weeks and Boyd v. United States, 116 U.S. 616 (1886), reveals that the basis of the exclusionary rule was the relationship between the fourth and fifth amendments which bars introduction of evidence seized in violation of the fourth.

50 Silverthorne Lumber Co. v. United States, 251 U.S. 385, 392 (1920).

ธ1 Id. 
The opinion recognizes that although a corporation could not have resisted a valid subpoena, "the rights of a corporation against unlawful search and seizure are to be protected even if the same result might have been achieved in a lawful way." ${ }^{252}$ Implicit in this statement is the notion that the ban on indirect use of illegally seized evidence depends in no way on what the government might or could have done, but rather on what was actually done. ${ }^{53}$

Two years after reversing a conviction based on a conversation overheard in violation of section 605 of the Federal Communications Act, ${ }^{\text {b4 }}$ the Supreme Court considered whether such illegally obtained evidence could be used for purposes other than introduction at trial. In Nardone $v$. United States, ${ }^{55}$ the Court refused to permit the prosecution to avoid an inquiry into its use of information gained by illegal wiretapping. The Court reasoned that to exclude only the exact words overheard, while permitting derivative use of the interception, "would largely stultify the policy which compelled" the reversal two years earlier. ${ }^{56}$

Silverthorne and Nardone were the first cases to develop the factsevidence theory. "[F]acts improperly obtained do not become 'sacred and inaccessible. If knowledge of them is gained from an independent source they may be proved like any others, but the knowledge gained by the Government's own wrong cannot be used by it simply because it is used derivately." location of stolen property, revealed by wiretapped conversations may be obtained from another source-for example, a party to the conversation-but that the conversation itself may not be used? The answer to this question should be no, if the party to the conversation ${ }^{68}$ was identified because of the illegal wiretap, for this would be a "derivative" use of illegally obtained evidence. However, if a third party tells the police the location of the stolen property, this fact, although revealed by the conversation, would be admissible if the third party's identity and information were discovered without the use of the wiretaps. This approach would require police to refrain from using illegally seized evidence to

52 Id.

53 See Bynum v. United States, 262 F.2d 465, 469 (D.C. Cir. 1958), discussed in text accompanying notes 241-43 infra.

54 Nardone v. United States, 302 U.S. 379 (1937).

55308 U.S. 338 (1939).

56 Id. at 340 .

57 Id. at 341 . One commentator suggests that the test is similar to the proximate cause concept in the law of torts. Thus, "no taint attaches to evidence unless such evidence is the natural, probable, and foreseeable consequence of the wire tapping." Bernstein, The Frtit of the Poisonous Tree: A Fresh Appraisal of the Civil Liberties Involved in Wiretapping and Its Derivative Use, 37 Ir工. L. REv. 99, 106 (1942).

58 See Goldstein v. United States, 316 U.S. 114 (1942). 
discover the independent source. If, on the other hand, the government learned of the conversation from a third party, and the conversation itself was evidence of a crime - a conspiracy-a formal reading of the Court's language would bar any testimony relating to the conversation.

Nardone cut down the logical radiations of the "fruit of the poisonous tree" doctrine by permitting experienced trial judges to reject sophisticated arguments which may prove a causal connection between information obtained through illicit wiretapping and the government's proof. The test as formulated excludes derivative evidence unless the "connection may have become so attenuated as to dissipate the taint." meaning of this language calls for a case by case approach with rehance on the "learning, good sense, fairness and courage of federal trial judges." ${ }^{" 60}$ Although concerned with a statutory violation, Nardone clearly indicates that in testing for the "fruit of the poisonous tree" the same criteria are used for both statutory and constitutional violations. ${ }^{61}$

Costello v. United States ${ }^{62}$ clarified the "attenuation of the taint" doctrine. Petitioner claimed that a large portion of the Government's case in his denaturalization proceeding rested on admissions made before a New York county grand jury investigating a judicial nomination. Alleging that he was impelled to make certain admissions concerning his illegal bootlegging activities because he believed that the district attorney had already received the information by use of illegal wiretaps, petitioner sought to invoke the "fruit of the poisonous tree" doctrine. ${ }^{63}$

The Court rejected this argument, reasoning that petitioner's admissions were not impelled by any fear of illegally secured evidence, but rather that petitioner readily admitted what was official and common

69 Nardone v. United States, 308 U.S. at 341.

${ }^{60} I d$. at 342 . The procedure has been described as vague and as leading to uncertainty but perhaps nevertheless justifiable, "for in placing control in the hands of the trial judge the admissibility of the evidence will be decided by the one best able to understand what the justice of the particular situation requires." 34 Irr. L. REv. 758, 759 (1940). This justification appears somewhat like the justification for the "voluntariness test" which also depended a great deal on the "common sense" of trial judges. See Kamisar, A Dissent from the Miranda Dissents: Some Comments on The "New" Fifth Amendment and the Old "Voluntariness" Test, 65 MICr. L. REv. 59, 94-104 (1966).

61 The suggestion has been made that a constitutional violation may present a stronger case for permitting the emanations of the initial illegality to "taint" other evidence than a rule stemming from a court's supervisory powers, at least in the context of a $M c N a b b$ Mallory violation. Kamisar, supra note 36 , at 101 . This point is somewhat analogous to the outrageous and innocent violation distinction discussed in text accompanying notes 15-20 supra. See MOder Code, supra note 16, at 76 (1966). Of course, if a distinction is made between violations of constitutional and statutory or court-made rules, the latter would be of no practical effect if the police are encouraged by the admissibility of the fruits to disobey them.

62365 U.S. 265 (1961).

68 Id. at 278 . 
knowledge. "[T] $]$ he 'fruit of the poisonous tree' doctrine excludes evidence obtained from or as a consequence of lawless official acts, not evidence obtained from an 'independent source.' ${ }^{264}$ Noting a previous examination before a federal grand jury which petitioner did not claim was infected with wiretapping, his arrest and subsequent trial for conspiracy to violate the liquor law, and his admission to the Bureau of Internal Revenue, the Court found it would defy common sense to hold that petitioner was impelled to tell the truth because of the intercepted telephone communications. The wiretaps revealed only the relationship between petitioner and a judicial nomination.

The vitality of the facts-evidence theory is not undermined by this holding, since the admission of bootlegging was impelled by knowledge obtained from an independent source-not by the illegal wiretaps. The Court conceded that the wiretaps "prompted" police to call petitioner before the grand jury investigating the judicial nomination. Petitioner's claim was simply that if the wiretapping prompted his appearance before the grand jury, and if he made statements in testifying which were later used against him, the use of the wiretapping resulted in the admissions. The Court disposed of the argument by quoting Nardone:

Sophisticated argument may prove a causal connection between information obtained through illicit wire-tapping and the Government's proof. As a matter of good sense, however, such connection may have become so attenuated as to dissipate the taint. ${ }^{.5}$

If, however, the wiretaps had disclosed information concerning the petitioner's bootlegging activity and he was therefore called before a grand jury investigating such operations, the statements would have probably been inadmissible. However, Costello's voluntary statement concerning his bootlegging activity was so distinct from his being called before the grand jury that to exclude the statement because he never would have been called but for the wiretapping, would carry the "fruit of the poisonous tree" doctrine too far. Thus, it appears that the initial illegality will not operate to exclude evidence when new independent activity by the defendant brings it forth.

The situation in the instant case may occur so infrequently that the exclusion of testimony would not deter sinilar activity by police who could not anticipate or foresee such results. JHowever, implicit in Costello is the idea that if petitioner believed the prosecutor already knew the answer to the questions because of an illegal search, and this was the only

64 Id. at 280 .

$65 I d$. 
reason that impelled the petitioner to answer, then these statements would be inadmissible in a subsequent proceeding. ${ }^{66}$

\section{B. Wong Sun v. United States ${ }^{67}$}

Wong Sun v. United States represents the most comprehensive Supreme Court decision concerning the "fruit of the poisonous tree." In that case, $A$, shortly after being illegally arrested, informed federal agents that $B$ possessed narcotics. When confronted by the agents, $B$ surrendered some heroin. Moreover, $B$, when arrested, made statements implicating $C$ in the narcotics racket. Several days after being lawfully arraigned and released on his own recognizance, $C$ voluntarily returned to make his statement. The federal agents conceded at trial that they would never have found the drugs without $A$ 's assistance.

The Court held that the narcotics were the "fruit of the poisonous tree" - $A$ 's illegal arrest-and set forth a two-part test to determine whether a subsequent discovery of evidence is tainted with the primary illegality:

1. The exclusionary rule has no application when the Government learns of the evidence "from an independent source."

With this one word Mr. Justice Brennan destroys the facts-evidence theory and holds that illegally obtained evidence is not sacred or inaccessible when the government learns of it froin a source separate and distinct from its own illegal activity. ${ }^{69}$

2. The rule has no application when the connection between the lawless conduct of the police and the discovery of the challenged evidence has become so attenuated as to dissipate the taint." "70

The Court then indicates that all evidence is not the "fruit of the poisonous tree" simply because it would not have come to light but for the illegal actions of the police. ${ }^{71}$ The controlling question in each case is:

[W] lether, granting establislment of the primary illegality, the evidence to which instant objection is made has been come at by ex-

86 Once outside of the grand jury room it appears as though the reasoning of this decision would exclude admissions derived from an interrogation based on illegally obtained evidence.

67371 U.S. 471 (1963).

68 Id. at 487, citing Silverthorne Lumber Co. v. United States, 251 U.S. 385 (1919) (emphasis added).

69 This statement has had a marked impact on the subsequent treatment of the doctrine. See text accompanying notes 254-59 infra.

70 Wong Sun v. United States, 371 U.S. at 487.

71 Id. at $487-88$. 
ploitation of that illegality or instead by mean sufficiently distinguishable to be purged of the primary taint.72

The Court held that the narcotics seized from $B$ could not be used as evidence against $A$ in the subsequent trial. They were fruit of the illegally obtained statement of $A$, and the connection between the statement and the narcotics was close enough to warrant excluding the evidence.

As for the narcotics seized from $B$, and their admissibility against $C$, a significant qualification was attached to the doctrine. The narcotics seized from $B$ were inadmissible against $A$ because $A$ 's statements led to their discovery and not because they were illegally obtained from $B$. $C$ 's statements were subsequent to the seizure and in no way contributed to their discovery. Therefore, $C$ was without standing to object to the fruit of the illegal seizure from $B$. According to the standing rule, before an individual may object to evidence as fruit of the poisonous tree, he must have a primary right to object to the "tree" itself." Moreover, $C$, after being unlawfully arrested, warned of his rights, questioned, and released, returned to make his confession. Such independent activity on his part after being warned was sufficient to remove any impact that remained as a result of his unlawful arrest. ${ }^{74}$ The compelling influences of the arrest were not the cause of $C$ 's statement.

III

ILIEGAI ARRESTS, ENTRIES, SEARCHES AND SEIZURES, AND THEIR FRUITS

\section{A. Illegal Arrests and Their Fruits}

\section{Confessions}

In Wong Sun, $A$ was arrested without probable cause. The Government argued that $A$ 's oral statements were admissible despite their being made after the police unlawfully broke into his dwelling, chased him down a hallway into a bedroom where his wife and children were sleeping, handcuffed and arrested him, and then said ".. . [Hom Way] says he got narcotics from you." "75

The statements, according to the Government's theory, were the product of an independent act of free will, ${ }^{76}$ and therefore admissible.

T2 $I d$. at 488.

73 See text accompanying notes 340-44 infra.

74 This situation is somewhat parallel to United States v. Bayer, 331 U.S. 532 (1947), where, some six months after confessing during an illegal detention, the defendant made a second confession. See text accompanying notes 187-89 infra. See also Thomas v. United States, 377 F.2d 118 (5th Cir. 1967).

75371 U.S. at 474.

76 Id. at 486. Despite the illegal nature of such an arrest, prior to Wong Sun it was the 
However, the Court found this verbal evidence, "which derives so immediately from an unlawful entry and an unauthorized arrest ... no less the 'fruit' of official illegality than the more common tangible fruits of the unwarranted intrusion." 77 The direct response to the Government's argument was that it was unreasonable to infer under the circumstances that the accused's statements were "sufficiently an act of free will to purge the primary taint of the unlawful invasion." 78 At a minimum, the Court appears to have ruled that an unlawful invasion and an unlawful arrest taken together are sufficient to exclude a contemporaneous oral statement. ${ }^{\text {.9 }}$

However, a number of courts have interpreted Wong Sun to exclude incriminating statements following an unlawful arrest only when oppressive events cause the statements and the arrest to become inextricably intertwined. ${ }^{80}$ While it is true that oppressive circumstances existed in

unchallenged rule that an illegal arrest did not automatically exclude an otherwise admissible confession or admission. Balbo v. People, 80 N.Y. 484, 499 (1880). For an excellent historical and analytical presentation of the rule see Kamisar, supra note 36, at 108-10. The rule in $B a l b o$ is derived from the same source as the rule that it is no defense to a criminal prosecution that the defendant was forcibly brought within the jurisdiction of the court. See Frisbie v. Collins, 342 U.S. 519 (1952).

77371 U.S. at 485 (emphasis added).

78 Id. at 486 .

78 N. Sobed, The New Confession Standards: Miranda v. Arizona 106 (1966). See also MODEr CODE, supra note 16, at 214 (1966).

Simce Wong Sun is a federal prosecution there is a question whether it is bimding upon the states. The Supreme Court's remand of Traub v. Connecticut, 374 U.S. 493 (1963), to be reconsidered in hight of Wong Sun and Ker v. California, 374 U.S. 23 (1963), strongly suggests an affirmative answer. See People v. Haven, $59 \mathrm{Cal}$. 2d 713, 381 P.2d 927, 31 Cal. Rptr. 47 (1963); State v. Mercurio, 96 R.I. 464, 194 A.2d 574 (1963). Contra, Dailey v. State, 239 Md. 596, 212 A.2d 257 (1964). See also Clewis v. Texas, 415 S.W.2d 654 (Tex. Crim. App. 1967), rev'd on other grounds, 386 U.S. 707 (1967). The Supreme Court, in reversing, specifically refrained from expressing an opinion on whether Wong Sun was applicable to state trials. 386 U.S. at 711 n.7. Despite the footnote in Clewis, one would imagine the common sense of the rule or the policy underlying the inadmissibility of fruit of the poisonous tree would mandate adoption without "compulsion" from the Supreme Court. See People v. Rodriguez, 11 N.Y.2d 279, 183 N.E.2d 651, 229 N.Y.S.2d 353 (1962); State v. Evans, 45 Hawaii 622, 372,P.2d 365 (1962); Note, Aftermath of Mapp v. Ohio: Collateral Problems in the Law of Evidence, 29 BRooktyn L. REv. 98, 107-08 (1962); Cf. Silver, The Supreme Court, the State Judiciary and State Crminal Procedure: An Example of Uncreative Federalism, 41 ST. JoENs L. REv. 331 (1967). But cf. Friendly, The Bill of Rights as a Code of Criminal Procedure, 53 CALIF. L. Rev. 929 (1965).

80 See Rogers v. Umited States, 330 F.2d 535 (5th Cir. 1964) where a three-liour period between the illegal arrest and the statement which was procured by noncontemporaneous questioming is distinguished from the oppressive circumstances of, for example, Wong Sun. See also United States v. McGavac, 337 F.2d 317 (6th Cir. 1964), cert. denied, 380 U.S. 933 (1965); Hollingsworth v. United States, 321 F.2d 342, 350-51 (10tl Cir. 1963); United States v. Burke, 215 F. Supp. 508 (D. Mass. 1963), aff'd, 328 F.2d 399 (1st Cir.), cert. denied, 379 U.S. 849 (1964) (accused advised of his right to counsel); Traub v. Connecticut, 151 Conn. 246, 196 A.2d 755 (1963), cert. denied, 377 U.S. 960 (1964); State v. Kitashiro, 48 
Wong Sun, the Court indicates in a footnote to the opinion that "[e]ven in the absence of such oppressive circumstances, and where an exclusionary rule rests principally on nonconstitutional grounds, we have sometimes refused to differentiate between voluntary and involuntary declarations." ${ }^{\prime 81}$ This ruling accords with the primary purpose of the exclusionary rule-deterring illegal pohice practices. Otherwise police would be fully aware that an illegal arrest per se would not vitiate any evidence obtained ${ }^{82}$ through interrogation, fingerprinting, ${ }^{83}$ or lineup identification. If the pohice suspect an individual of a possession crime, they could risk an unlawiful arrest reasoning that if the suspect has the "goods" on him there is an excellent chance that he may confess after realizing the game is up. ${ }^{84}$ Therefore, Wong Sun should stand for the

Hawaii 204, 397 P.2d 558, 561-62 (1964); State v. Lavallee, 104 N.H. 443, 189 A.2d 475 (1963); State v. Jackson, 43 N.J. 148, 203 A.2d I (1964).

Each of the above cases involved police station interrogation and the statements so obtained would be inadmissible under Miranda v. Arizona, 384 U.S. 436 (1966). Contra, Gatlin v. United States, 326 F.2d 666 (D.C. Cir. 1963) (holding illegal arrest sufficient to exclude statement); State v. Mercurio, 96 R.I. 464, 194 A.2d 574 (1963). See also People v. Haven, 59 Cal. 2d 713, 381 P.2d 927, 31 Cal. Rptr. 47 (1963). Commonwealth v. Palladino, 346 Mass. 720, 195 N.E.2d 769 (1964), best illustrates the problem. The court excluded statements made immediately after arrest but admitted statements made an lour later.

81 Wong Sun v. United States, 371 U.S. at 486 n.12.

82 "If law enforcement officers realize that evidence will be unavailable in court, they will probably refrain from inaking unlawful arrests designed to obtain that evidence." Note, 69 Yaxe L.J. 432, 436 (1960). Fingerprints are easily available without arrest, and it is doubtful that police would arrest solely to procure such evidence especially since the unlawful arrest inay result in the exclusion of other evidence. Id.

83 The argument lias been advanced that since fingerprints are not the objects of illegal arrests and the connection between the two almost de mininus, their exclusion is unwarranted. See Note, 69 Yare L.J. 432 (1960). No such claim is made for the contemporaneous incriminating statement, and it appears that one of the purposes of illegal arrests is to procure such statements. See W. La Fave, Arrest: The Decision to Take a Suspect nuto Custody 430-31 (1965).

84 People v. Macias, 180 Cal. App. 2d 193, 4 Cal. Rptr. 256 (1960), is an analogous case. Defendant was arrested by the police for his complicity in a robbery. He was handcuffed, placed in a police car, and informed that he would be searched at the stationhouse. Macias then disclosed that he had marijuana in his possession. The prosecution claimed that Macias voluntarily admitted possession of the narcotics. The court replied:

[Defendant] was acting under the immediate influence of the unlawful arrest and the threat and assurance that he would be searched at the police station. It was while le was in the police car on the way to the police station that he adinitted that he had four marijuana cigarettes on his person. Handcuffed, he was physically unable to resist a search and, having been arrested for the avowed purpose of accomplishing a search at the police station, he knew that further concealment or oral resistance was futile. Thus coerced, he confessed. That confession was the immediate product of the unlawful arrest, "the fruits of such unlawful conduct."

Id. at 197-98, 4 Cal. Rptr. at 259-60.

It is also possible that upon arrest, even before a single question is asked, or a warning given a person may attempt to exculpate himself but in doing so may make incriminating statements. Compare People v. Macias, supra, and People v. Stewart, 232 Mich. 670, 206 
proposition that statements accompanying a bare illegal arrest are entitled to the benefit of the exclusionary rule.

If no adverse consequences to the state result from an illegal arrest, this no doubt will encourage such activity especially in light of other restrictions on police. The deterrence-causation theory is designed to discourage the police from defying "the Constitution on the hope or expectation that somewhere along the way the prisoner" will thereafter volunteer an admissible statement. ${ }^{85}$ Thus, the illegal arrest need not be the proximate or effective cause of the statement; but rather, there need only be some connection between the confession and the illegal arrest to offer a logical basis for excluding the statement. ${ }^{86}$ If it is reasonable to conclude that certain proscribed police activity is deliberately designed to obtain such evidence, or that its procurement can be reasonably anticipated, then the confession should be suppressed to deter continuance of the activity.

\section{Unlawful Arrests and Attempted Bribery}

An interesting situation arises when an individual who is unlawfully arrested attempts to bribe the arresting officers to "forget" what has happened. In Perdiz v. United States defendant, after his arrest, attempted to bribe the arresting officer. In dealing with the statements of bribery, the District Court Judge distinguished Wong Sun as being inapplicable to a situation where an independent criminal act is committed. ${ }^{87}$

N.W. 337 (1925), with Smith v. United States, 254 F.2d 751 (D.C. Cir. 1958). See La Fave, Search and Seizure: "The Course of True Law . . Has Not . . Run Smooth," 1966 Irr. L. FoR. 255,373 . If the contemporaneous incriminating statement is found to be admissible, this may only encourage illegal arrests-a problem which is becoming nore acute than is generally realized. See A. Barth, The Price of Liberty 47 (1961); M. Houts, From Arrest to Rerease 24 (1958); A. Trebach, The Rationing of Justice 4-7 (1964); Douglas, Vagrancy and Arrest on Suspicion, 70 Yare L.J. 1 (1960); Foote, Law and Police Practice: Safeguards in the Law of Arrest, 52 Nw. UL. Rev. 16, 20 (1957); Kamisar and Choper, The Right to Counsel in Minnesota: Some Field Findings and Legal-Policy Observations, 48 MINN. L. REv. 1, 48 (1963); La Fave, Detention for Investigation by the Police: An Analysis of Current Practices, 1962 WASE. U.L.Q. 331, 362-64.

$85 \mathrm{Kamisar}$ supra note 44 , at 137 . Therefore where the resulting evidence is obtained purely by nistake-for example, police request to see a person's license, and lottery tickets are inadvertently given, Acklen v. State, 196 Tenn. 314, 267 S.W.2d 101 (1954)-then there is no real pohicy grounds for excluding such evidence. $C f$. District of Columbia v. Perry, 215 A.2d 845 (1966).

86 See United States v. Perdiz, 256 F. Supp. 805 (S.D.N.Y. 1966).

87 Id. at 806 . At least the District Court Judge recognized the possible applicability of Wong Sun. See Vinyard v. United States, 335 F.2d 176 (8th Cir.), cert. denied, 379 U.S. 930 (1964), where the only question considered was whether, as a natter of substantive criminal law, one can be convicted of attenipting to bribe an officer although the arrest niay be unlawful. The court found that as long as the agent's actions were in official form and done under color of law, unlawful arrest is innuaterial. But see Troop v. United States, 235 F.2d 123 (7th Cir. 1956); United States v. Morrison, 10 U.S.C.M.A. 525, 28 C.M.R. 91 (1959). 
If we assume that statements made immediately during or after an unlawful arrest are to be excluded, regardless of their "voluntary" nature, there appears no purely logical reason why "voluntary" statements made during an illegal arrest which constitute independent criminal acts should be treated differently. If, in narcotics cases, arrests are often made on less than probable cause, one might infer that the police anticipate an attempted bribe and will arrest in the hope of being bribed in order to "get their man." Bribery is, however, certainly not as foreseeable as the incriminating statement. If such bribes "are so few and unpredictable that admission of the evidence ... . would not encourage future illegal arrests ... to accomplish the same result, then the evidence should be received." $\$ 8$

Perhaps the decision in Perdiz is an example of the "learning, good sense, fairness . . . of federal trial judges" 80 who determine "what the justice of the particular situation requires." tion that the bribe was an independent criminal act or was not the inherent product of the arrest "ignores the basic issues involved and furnishes wholly inadequate criteria for future decision making." characterization of the bribe as an independent criminal act may be shorthand for a finding that bribes are not anticipated or foreseeable. In any event, the question which should be asked is whether the bribe was the likely or probable anticipated or foreseeable product of the arrest, and in this context its status as an independent criminal act is irrelevant.

\section{Unlawful Arrests and "Spontaneous Statements"}

After being unlawfully arrested a suspect may "accidentally" meet the victim and make some spontaneous gesture or admission. If there has been no actual interrogation, a Miranda warning may not be necessary. However, arranging a confrontation between suspect and victim in the expectation and hope that the meeting will precipitate an admission is, under the author's reading of Miranda, an interrogation necessitating a warning. ${ }^{92}$

\footnotetext{
${ }^{88}$ La Fave, Search and Seizure: "The Course of True Law . . . Has Not . . . Run Smooth," 1966 ILL. L. For. 255, 374.

89 Nardone v. United States, 308 U.S. at 342.

80 Note, 34 IrI. L. REv. 758, 759 (1940).

91 Note, 8 U.C.L.A.I. REv. 454, 457 (1961).

92 If the very purpose of the "arrest" is to arrange such a confrontation, then the unsolicited, spontaneous statenients should be excluded. The failure to give a Miranda warning is strong authority for exclusion, since it could be clear that the confrontation was dehberately designed to evoke a response. See Rothblatt and Pitler, Police Interrogation: Warnings and Waivers-Where Do We Go from Here? 42 NoTre DaMe LAw. 479 (1967) for the view that in such a situation a Miranda warning is required. A deterrence rationale could be used to exclude such statements regardless of the intention of the police. See also United States $v$.
} 
If, however, such a situation is held not to amount to an interrogation, another question is presented. If the police have called the victim and requested him to be at the stationhouse, then the "spontaneous statement" was foreseeable. An arrest may be designed to permit this fortuitous meeting to occur. Therefore the exclusion of resulting statements would be desirable to remove an added incentive for the illegal arrest. If the Supreme Court's decision in Miranda results in this type of avoid and evade tactic, ${ }^{93}$ then such activity must be closely examined to protect rights which exist independently of the fifth amendment's privilege against self-incrimination. ${ }^{94}$

\section{Illegal Arrests: Seizure of the Person}

Situations will arise where despite illicit police activity the Supreme Court will nevertheless affirm a conviction without attempting to utilize an exclusionary rule. In Frisbie v. Collins ${ }^{95}$ petitioner alleged that he was forcibly removed from Mllinois to Michigan by officials of the latter state. Collins claimed that his forcible removal and subsequent involuntary appearance in Michigan was insufficient to vest jurisdiction in the courts of Michigan.

The Sixth Circuit held that petitioner was entitled to a writ of habeas corpus, ${ }^{96}$ reasoning that the Michigan officials violated the Federal Kidnapping Statute, and that to permit Collins to be tried "would in practical effect lend encouragement to the commission of criminal acts by those sworn to enforce the law." "due process of law is satisfied when one present in court is convicted of crime ... after a fair trial in accordance with constitutional procedural safegnards. There is nothing in the Constitution that requires a court to permit a guilty person rightfully convicted to escape justice because he was brouglit to trial against his will."198

The Court apparently thought it of hittle consequence that the petitioner had been arrested under circumstances, which, if true, would amount to an unlawful seizure of the person in violation of the fourth amendment. Frisbie, of course, was decided prior to Mapp. As to the

Meachum, 197 F. Supp. 803 (D.D.C. 1961). Although to date the data appears to indicate, if anything, that the police may be somewhat "overreading" Miranda, see N.Y. Times, Feb. 26, 1967, $\& 4$, at 12, col. 1, it is doubtful that the cases which actually arise will bear out such treatment.

98 See Rothblatt and Pitler, supra note 92, at 486.

94 See Bynum v. United States, 262 F.2d 465 (D.C. Cir. 1958), and text accompanying notes 118-29 infra.

95342 U.S. 519 (1952).

98189 F.2d 464 (6th Cir. 1951).

97 Id. at 468.

98 Frisbie v. Collins, 342 U.S. at 522 . 
Sixth Circuit's reliance on the Federal Kidnapping Statute, the Court refused to "read in" a sanction which would divest courts of jurisdiction, reasoning that this was a task for Congress rather than the Court. It would have been an easy matter to follow the Sixth Circuit but apparently the Court could not be convinced than an individual who was given all of the constitutionally required procedural safeguards and found guilty should be permitted to go free.

This view concerning constitutional safeguards appears to beg the question. Is not the individual who is unlawfully searched also given all of his procedural rights-after the searcli? The decision in Frisbie is difficult to reconcile with the policy of discouraging official lawlessness as manifested by $M a p p$ and other recent decisions. ${ }^{00}$

It is not readily apparent why the exclusion of illegally obtained evidence may be a proper way to deter illicit police activity while the divesting of jurisdiction is not. Why was it necessary for the Michigan authorities to illegally seize Collins? They surely could have requested extradition by Illinois authorities instead of violating federal law and the Federal Constitution. If in certain situations extradition cannot be achieved is it defensible for the government-state or federal-intentionally to violate the law to obtain jurisdiction over a prospective defendant? ${ }^{100}$

If extradition could not have been achieved lawfully did not the police "profit by" their illegal kidnapping just as much as the officer who illegally seizes evidence? ${ }^{101}$ Where the authorities cannot legitimately obtain jurisdiction over an individual, divesting the court of jurisdiction is the only method of deterring Frisbie-type conduct. ${ }^{102}$

${ }^{00}$ See Scott, Criminal Jurisdiction of a State over a Defendant Based upon Presence Secured by Force or Fraud, 37 MivN. L. REv. 91, 97 (1953), where the author equates the inadequate remedies against offending officers for abduction to the remedies which were available for illegal searches and seizures. "[T] $]$ he only effective way to deter police from such lawlessness is to say to them, "We will not try a criminal whose presence in the state has been thus secured." Id. at 102 .

100 See Allen, Due Process and State Criminal Procedures: Another Look, 48 Nw. U.I. REv. 16, 28 (1953), where the author suggests that in situations such as Frisbie, where the police conduct was flagrant and willfully illegal, it is extremely questionable whether the Frisbie doctrine should apply.

101 The Supreme Court has indicated that an illegal arrest per se violates the Constitution. See Henry v. United States, 361 U.S. 98, 100-01 (1959); Giordenello v. United States, 357 U.S. 480, 485-88 (1958). The fourth amendment assures "the right of the people to be secure in their persons"; thus, an arrest is a seizure of the person. See N. LASSON, THE HisTORY AND Developarent of the Fourth Amendment to the United States Constitution 79-82 (1937); Fraenkel, Concerning Searches and Seizures, 34 Harv. L. Rev. 361 (1921). See also Barrett, Personal Rights, Property Rights, and the Fourth Amendment, 1960 Sup. Cr. REv. 46,47 (suggesting that an unlawful arrest may be a greater invasion of privacy than the unlawful seizure of a man's property); Foote, Law and Police Practice, Safegiards in the Law of Arrest, 52 Nw. U.L. REv. 16, 41-42 (1957).

102 See Scott, silpra note 99 , at $99-102$. 
Whatever the soundness and continued vitality of Frisbie in a multijurisdictional context, a different problem is presented when an illegal arrest occurs in the same jurisdiction where the arrestee is tried. ${ }^{103}$ Ironically, although Mapp, Wong Sun, and Miranda have made Frisbie more anomalous conceptually, they have weakened the argument for overruling it.

An individual who is illegally arrested nnay be able to suppress statements made during his illegal custody. ${ }^{104}$ In addition, any physical evidence disclosed as a result of a search incident to the unlawful arrest is inadmissible. ${ }^{105}$ In intra-jurisdictional settings these exclusionary rules have greatly lessened the significance and objectionability of Frisbie. If there is no other legal evidence against the defendant, he will be set free. If the suspect is forced to go to trial and there is sufficient admissible evidence to convict, it should not be necessary to have a new trial merely because the entire process was commenced by an illegal arrest. ${ }^{108}$ Surely it is an excuse in futility to release the defendant and then immediately rearrest him based on evidence unrelated to the first arrest.

On the other hand, reversing convictions because jurisdiction has, in effect, been unlawfully obtained, nnakes some logical sense in terms of deterring unlawful arrests. ${ }^{107}$ However, it appears necessary to draw a line where logic interferes with the criminal process without any meaningful gain to society. The constitution prohibits unlawful seizures of the person. However, the requirement to warn a defendant of his rights, the exclusion of contemporaneous statements, and the inadmissibility of any evidence discovered as a result of the arrest operate to remove most of the incentive to arrest unlawfully. If experience reveals that these rules do not so operate then additional sanctions may become necessary.

\section{B. Miranda and Wong Sun}

Although the Supreme Court's decision in Miranda v. Arizona ${ }^{108}$ did not deal directly with the "fruit of the poisonous tree,"100 it is neverthe-

103 One commentator suggests that the problems of an illegal arrest and the jurisdiction of the court in a single state context may have been one reason why the Supreme Court decided Frisbie the way it did. Allen, supra note 100, at 28. See Roberts v. Commonwealth, 417 S.W.2d 234 (Ky. 1967).

104 See text accompanying notes 108-29 infra.

105 Johnson v. United States, 333 U.S. 10 (1948).

${ }^{108}$ See text accompanying notes $240-44$ infra.

107 The argument that an illegal arrest requires the dismissal of a prosecution has been rejected by at least two jurisdictions. Commonwealth v. Bishop, $425 \mathrm{~Pa} .175,228$ A.2d 661 (1967); Sexton v. State, 228 A.2d 605 (Del. 1967).

108384 U.S. 436 (1966).

109 See text accompanying notes 167-94 infra. 
less necessary to present a brief discussion of that case. Miranda involved four legal arrests and subsequent incommunicado police interrogation resulting in confessions by each of the defendants. The Supreme Court had for some time struggled with the problems of secret interrogations by using a voluntariness standard for testing confessions. ${ }^{110}$ This standard was designed to determine whether a confession was intelligently and rationally made-a test which necessarily depended upon the subjective view of each judge applying the standard. ${ }^{311}$

The difficulty with the voluntariness test was its failure to provide stable guidelines to remove this subjective element. ${ }^{112}$ It was impossible for the Supreme Court to consider each of the cases which came to it through habeas corpus or direct appeal, ${ }^{113}$ and the desirability of a more automatic standard was readily apparent. ${ }^{114}$ The Court held in Miranda that the fifth amendment required that when a suspect is in police custody and before he is questioned the pohice must warn the suspect:

1. that he has the right to remain silent;

2. that anything he says can be used against him in a court of law;

3. that he has the right to the presence of an attorney; and

4. that if he cannot afford an attorney one will be appointed for him prior to any questioning if he so desires.

The defendant may waive any or all of these rights but such a waiver must be the product of a rational intellect and free will. It appears that the waiver will be judged by the voluntariness standard and may become as difficult to apply as the old standard. ${ }^{115}$ Similarly one might forcefully argue that police warnings are inadequate to inform the suspect of his rights. ${ }^{116}$ For the present however, if they are properly given, the Court apparently finds such warnings the best method of balancing the privilege against self-incrimination and society's need for police questioning. ${ }^{117}$

110 See generally Herman, The Supreme Court and Restrictions on Police Interrogation, 25 Оппо Sт. L.J. 449 (1964); Paulsen, The Fourteenth Amendment and the Third Degree, 6 STAN. L. REV. 411 (1954).

111 See Kamisar, A Dissent From the Miranda Dissents: Some Contments on the "New" Fifth Amendment and the Old" "Voluntariness" Test, 65 Micrr. L. Rev. 59, 94-104 (1966).

112 In Colombe v. Connecticut, 367 U.S. 568 (1961), Mr. Justice Frankfurter attempted to define the standard in a sixty-seven page opinion which was announced as the judgment of the Court. Only Mr. Justice Stewart concurred in the opinion. See generally Kamisar, What Is an "Involuntary" Confession?, 17 Rutcers L. REv. 728 (1963).

113 See the statement of Mr. Justice Black during the Miranda oral argument. Unofficial Transcript of Oral Argument in Miranda and Companion Cases 91 (on file in University of Michigan Law Library.)

114 See W. Schaefer, THe Suspect and Society 10 (1966).

115 See Elsen and Rosett, Protections for the Suspect Under Miranda v. Arizona, 67 CorJur. L. REv. 645, 658-59 (1967).

116 See Rothblatt and Pitler, supra note 92, at 492.

117 See Kamisar, Miranda v. Arizona, Some Comments on the Old New Fifth Amend- 
In light of Miranda it becomes necessary to reconsider what remains of Wong Sun. In Wong Sun, $A$ was illegally arrested and told by a government agent that an informer had said that he possessed narcotics. The facts clearly indicate that $A$ was in custody, and the sole question is whether the statement by the agent was sufficient to constitiute an interrogation necessitating a warning. The mere fact of arrest has been characterized as compulsive in nature, ${ }^{118}$ and under the circumstances of Wong Sun the statement was intended to evoke a response. ${ }^{119}$ Therefore, it appears that $A$ was entitled to a Miranda warning before any attempt to obtain a confession.

The question is whether, had the appropriate Miranda warnings been given in Wong Sun, this would have been sufficient to purge the primary taint of the illegal arrest. ${ }^{120}$ The question does not lend itself to the simple answer that if the suspect had never been arrested, he never would have confessed. This would be a utilization of the "but for" criterion which was rejected by Wong Sun. Wong Sun may be viewed as merely an intermediate step to Miranda. ${ }^{121}$ If this is true, Miranda now makes it unnecessary to exclude statements obtained after an unlawful arrest because the necessity to warn the suspect will sufficiently deter such arrests. ${ }^{122}$ The implication of this reading of Miranda is that the protection of the fifth amendment's privilege against self-incrimination through a system of police warnings has made unnecessary the fourth amendment's privilege unreasonable seizures of the person. ${ }^{123}$ Perhaps it is unfair to say that the protections of the fourth amendment are unnecessary; it is better to say that the exclusion of statements after a police warning and a valid waiver is not the way to deter unlawful arrests. The remedy of a civil action for false arrest may be an appealing method for deterring violations of the

ment, in Proceednags, Conference of State Governanents 47 (Council of State Governments 1966).

118 See Kamisar, supra note 44 , at 87 n. 42.

119 See Rothblatt and Pitler, supra note 116, at 486.

120 At least three appellate courts have answered this question affirmatively. See State v. Hooper, 10 Ohio App. 2d 229, 227 N.E.2d 414 (1966); Pearson v. State, 414 S.W.2d 675 (Tex. Crim. App. 1967); State v. Vangen, - Wash. 2d -, 433 P.2d 691 (1967) (dicta). See also Pennsylvania ex rel. Craig v. Marony 348 F.2d 22 (3d Cir. 1965), cert. denied, 384 U.S. 1019 (1966), wherein a defendant was illegally arrested but had been advised by his attorney to remain silent, and some five days later a magistrate also advised him of his rights. Cf. Manuel v. United States, 355 F.2d 344 (5th Cir. 1966); People v. Sesslin, 252 A.C.A. 130, 60 Cal, Rptr. 30 (1967) (dicta).

121 Cf. Note, Criminal Proceducre-Fourth Amendment Vitality of Wong Sun, 19 RUTGers

L. REv. 140, 149 (1964).

122 Cf. Kamisar, Some Comments on the "New" Fifth Amendment, in ProceEdings, Eighteenth Annoal Meeting of the Conference of ChefF Justices 45 (1967). ${ }^{123}$ See Graham, What is "Custodial Interrogation"?: California's Anticipatory Application of Miranda v. Arizona, 14 U.C.L.A.L. REv. 59, 93 (1966). 
fourth amendment. ${ }^{124}$ However, if history is a proper guide, adopting this type of prophylactic device would only repeat the error of Wolf $v$. Colorado. ${ }^{125}$

On the other hand the police may fear that arresting or placing an individual in a situation necessitating a Miranda warning would prompt an exercise of the privilege, thus removing the possibility of a confession. Additionally, the exclusion of the "spontaneous statement" made during an unlawful arrest may induce the police to be extremely careful before placing an individual in custody. However, the average man illegally arrested is probably unaware that he is free to go at any time. The Miranda warnings were designed to protect the privilege against self-incrimination, and if the warnings are held to "purge the taint" of the illegal arrest, police may arrest on any grounds, give the warnings and hope they will receive a waiver. ${ }^{126}$

Perhaps, when we are concerned with dragnet arrests, and this is known to the arrested individuals, the courts may require a heavier burden to establish a waiver of a different type of warning to permit waiver. But, what of the other types of illegal arrest that involve no more "coercion" than the lawful arrest? ${ }^{127}$ The privilege against self-incrimination may have higher standing in the table of societal values than freedom from unlawful arrests. However, to regard the latter right as insignificant would be grossly to devalue the diguity of the individual. ${ }^{128}$

To hold that Miranda warnings "purge the taint" of illegal arrests may lead to unlawful arrests ${ }^{129}$ made in the hope of obtaining a waiver in order to regain the right to interrogate-something that law enforcement officials claim to have lost by that very decision.

\section{Illegal Entries, Searches and Seizures, and Incriminating Statements}

\section{Illegal Entry}

The Supreme Court in Wong Sun held that incriminating statements obtained after an unauthorized entry and illegal arrest are inadmissible $e^{130}$

${ }^{124}$ Cf. McGarr, The Exclusionary Rule: An Ill-Conceived and Ineffective Remedy, 52 J. CrRm. L.C. \& P.S. 266, 267 (1961); Plumb, Illegal Enforcement of the Law, 24 CorNerx L.Q. 337, 387 (1939).

125338 U.S. 25 (1940). See generally Allen, Federalism and the Fourth Amendment: A Requiem for Wolf, 1961 Sup. CT. Rev. 1; Kamisar, Public Safety v. Individual Liberties: Some "Facts" and "Theories," 53 J. CRns. L.C. \& P.S. 171 (1962); Paulsen, The Exclusionary Rule and Misconduct by the Police, 52 J. Crma. L.C. \&: P.S. 255 (1961).

126 Cf. MOdes Code, supra note 16, at 65.

- 127 Even before Miranda there was much concern over the number of illegal arrests being undertaken by law enforcement officials. See materials cited in note 84 supra. ${ }^{128}$ See Barrett, Personal Rights, Property Rights and the Fourth Amendment, 1960

SUr. CT. REv. 46. ${ }^{129}$ See Ruffin, Out on a Limb of the Poisonous Tree, 15 U.C.I.A.L. Rev. 32, 69 (1968). 180371 U.S. at $485-86$. 
leaving open the question whether an illegal entry alone will operate to exclude testimony. However, at the end of the discussion there is a citation to Nueslein v. District of Columbia, ${ }^{131}$ in which the police, while investigating a minor traffic accident, went to the home of the defendant, who owned a taxicab which had struck a parked car. They knocked on the front door, and, receiving no answer, entered the house without a search or arrest warrant.

When confronted by the police, the defendant admitted that he was driving the taxi at the time of the accident. The police believed that Nueslein was drunk. He was then arrested and subsequently convicted of operating a motor vehicle while under the influence of alcohol. The court considered the admissibility of the defendant's statement that he was operating a vehicle. Reasoning that the police were "in position"132 to see and to hear the defendant only because of the illegal entry and that admitting the statement would encourage the police to "proceed in an irregular manner on the chance all will end well,"133 the court excluded the statement. The civil remedy against the officers was found to be insuffcient, involving expense, delay, and unwanted publicity. The criminal sanction against the officers was also found wanting in being either too lax or too strict. ${ }^{134}$ The court held that the security and sanctity of the home outweighed the pohicy of bringing misdemeanants to task, and a simple, effective way to assure that the fourth amendment's right of privacy is secured is to exclude the evidence obtained after an illegal entry. ${ }^{135}$

The argument was advanced that the evidence obtained should have been admissible because petitioner could not have objected "if the officers, remaining outside, had called into the house and accomplished the same results."130 However, in removing the incentive to engage in illegal activity-the procuring of admissible confessions-these legitimate means are in no way impinged. As a matter of policy these are the very practices

181115 F.2d 690 (D.C. Cir. 1940).

132 Id. at 693. Cf. McDonald v. United States, 335 U.S. 451, 458-59 (1948) (Jackson, J., concurring). If an unlawful entry puts the police in position to observe "ongoing criminality" other than that which they are looking for-entering a house to arrest for prostitution and discovering a "pot party"-then, at least in the vice area, such observation should be excluded. Broeder, Wong Sun v. United States: A Study in Faith and Hope, 42 Neb. L. Rev. 483,549 (1963). Of course, a police officer may not testify about that which cannot be offered into evidence. McGinnis v. United States, 227 F.2d 598 (1st Cir. 1953).

133 Nueslin v. District of Columbia, 115 F.2d 690, 694 (D.C. Cir. 1940).

134 Id. at 695 .

${ }^{135}$ See People v. Mitchell, 251 Cal. App. 2d 727, 59 Cal. Rptr. 677 (1967), wherein the court held that defendant's consent to search his apartment, given to the police who had illegally entered the apartment, was invalid.

$136 \mathrm{~J}$. MAGUIRE, EVDENCE OF GUIIT 188 (1959). This author is primarily concerned with the concept of an intangible being within the protection of the fourth amendment. This argument was rejected in Wong Sun, 371 U.S. at 485. 
which an exclusionary rule seeks to encourage, and the Nueslein opinion properly considered what in fact was done rather than what could or should have been done. ${ }^{137}$

\section{Illegal Searches and Seizures}

It seems more probable and natural for the individual to make a contemporaneous oral statement during an illegal search ${ }^{138}$ or immediately upon an unlawful seizure of evidence than upon simple illegal entry. Therefore, such illegal search and seizure is said to present a stronger case for exclusion than either the illegal arrest or unlawful entry. ${ }^{\mathbf{1 3 0}}$

In Quan v. State, ${ }^{140}$ defendant, during the course of a search made pursuant to a defective warrant, made several incriminating statements. The Supreme Court of Mississippi admitted the statements reasoning that the defendant knew of his right to remain silent, and that therefore the statements were not the inherent product of the search but the result of a deliberate decision to waive the privilege against self-incrimination. ${ }^{141}$ There is no indication in Quan that any evidence was found, and therefore, the statements were apparently made under the same circumstances as an illegal arrest or an unlawful entry. In fact, the court rejected the argument that the illegal search "puts the accused under an unlawful restraint or under a sort of illegal oppression, or surrounds him with an unlawful pressure," ${ }^{142}$ as being no more persuasive than the arguments advanced for the exclusion of statements made during an unlawful arrest.

However, a search is more conducive for eliciting statements than a bare illegal arrest or illegal entry. One can readily imagine Quan following the officers around and speaking to them as they searched his home. Underlying this decision is the assumption that the suspect was aware of his rights to remain silent, and that he knowingly waived this privilege by speaking. In such a situation it is more likely that the suspect froze $\mathrm{e}^{148}$ and was unaware of his right to remain silent. It seems fair to conclude that searching the home in the presence if its resident amounts to "custodial interrogation" necessitating a Miranda warning. If, however, this was not a "custodial interrogation" and a warning was neither required nor given, then Wong Sun should apply.

The other basis for the Quan decision was the absence of policy

187 What could or should have been done is significantly different from what inevitably would have been done. See text accompanying notes 254-65 infra.

188 See People v. Faris, 63 Cal. 2d 541, 407 P.2d 282, 47 Cal. Rptr. 370 (1965).

139 See Kamisar, supra note 44, at 83-87.

140185 Miss. 513, 188 So. 568 (1939).

141 Id. at $520-21,188$ So. at 569 .

142 Id. See also Rohling v. State, 230 Ind. 236, 244, 102 N.E.2d 199, 202 (1951).

${ }^{143}$ See United States v. Rutheiser, 203 F. Supp. 891 (S.D.N.Y. 1962). 
grounds for excluding such contemporaneous and "voluntary" statements. However, the same rationale which underlies the exclusion of "volunteered" statements during the course of an unlawful arrest or illegal entry are applicable to this situation. If there is an incentive for police to search unlawfully with the hope that the suspect will incriminate himself, and the pressure inherent in the search makes such a result more probable than not, then any statement made during such a search should be inadmissible.

Where there is an actual illegal seizure, the realization that the "cat is out of the bag" plays a significant role in encouraging the suspect to speak. In fact, the Ninth Circuit has held that all declarations and statements after the illegal seizure of documents made "under the compulsion of the things so seized, are affected by the vice of primary illegality."144 The principle that a search whicln is unlawful at its inception will not be made lawful by what it turns up underlies the exclusion of the contemporaneous oral statement made during an illegal searcll. ${ }^{145}$ Unless sucl evidence is excluded, the police may violate the mandates of the fourth amendment, knowing that any tangible evidence discovered will be inadmissible, but hoping they can procure an incriminating statement whicls will make their activity worthwhile. ${ }^{140}$ "At best [the confession] serves merely to prove that the officers guessed correctly."1147 The purpose of an exclusionary rule is to assure that officers, rather than "guess," act in accordance with the requirements of the fourth amendment.

IV

EXCLUDING IILEGALLY OBTAINED CONFESSIONS

\section{A. Confrontations with Illegally Seized Evidence and Induced Confessions}

The Supreme Court, in Fahy v. Connecticut, ${ }^{148}$ reversed the conviction of a man accused of painting swastikas on a synagogue, holding that the introduction of a can of paint and a brush obtained in an illegal search and seizure was not harmless error and that the defendant sliould be given an opportunity "to show that his admissions were induced by being confronted with the illegally seized evidence."148 The test appears to be whether the defendant was notivated to make the statement when

144 Takahashi v. United States, 143 F.2d 118, 122 (9th Cir. 1944).

146 United States v. Setaro, 37 F.2d 134 (D. Conn. 1930); In re Oryell, 28 F.2d 639

(W.D.N.Y. 1928). See also Haynes v. State, 110 Tex. Crim. 553, 9 S.W.2d 1043 (1928).

146 See Broeder, supra note 132, at 531.

147 United States v. Setaro, 37 F.2d at 137.

148375 U.S. 85 (1963).

140 Id. at 91 . 
confronted by the evidence obtained during the illegal search. ${ }^{150}$ State $v$. Kitashiro ${ }^{151}$ presents a well reasoned analysis of the problem.

The defendant was arrested, and during the ride to headquarters police told him that since he possessed stolen automobile parts, he might as well tell the truth. ${ }^{152}$ In fact the police had procured the parts by an illegal search and seizure. This warning to tell the truth is implicit whenever the suspect knows or sees for himself that the police liave seized (albeit illegally) incriminating physical evidence.

At the police station, before his confession, the defendant's father told him that he had spoken with a lawyer wlio advised the son to say nothing. The Hawaiian supreme court found that the police statements about the parts, knowledge of which was obtained througl official illegality, were used "to instill in defendant a realization of the lopelessness of his situation." ${ }^{1153}$ It was argued that the fifteen minute talk with the father along with the warning to remain silent removed the impact of the police statements. The court, however, ruled the confession inadmissible, finding that there was no actual consultation with a lawyer and that the defendant, feeling defenseless in the face of a hopeless situation, therefore confessed. ${ }^{154}$

This case illustrates the police tactic of attempting to use illegally seized evidence as leverage to obtain a confession. The psychological effect on the suspect is overwhelming. He is struck with the helplessness of the situation, and it takes a great deal to remove the effect. The Miranda warnings are designed to neutralize the ordinary intimidation and helplessness of custody but not the extra intimidation of either a

150 People v. Bilderbach, 62 Cal. 2d 757, 401 P.2d 921, 44 Cal. Rptr. 313 (1965). The court found the question to be one of fact-that is whether there was a sufficient relationship between the illegal search and the confession. If such a relationship is found to exist then the confession must be excluded or else the exclusionary rule would he effectively avoided. See Broeder, supra note 132, at 548. The California experience with illegally seized evidence inducing statements has been somewhat confusing although Bilderbach and People v. Faris, 63 Cal. 2d 541, 407 P.2d 282, 47 Cal. Rptr. 370 (1965) appear to clear up the difficulty. Combpare People v. Dixon, 46 Cal. 2d 456, 296 P.2d 557 (1956) with People v. Ambrose, 155 Cal. App. 2d 513, 524-25, 318 P.2d 181, 188-89 (1957) (alternate holding). For a discussion of these latter two cases see Kamisar, supra note 44 , at $87 \mathrm{n.42}$.

15148 Hawaii 204, 397 P.2d 558 (1964).

152 Id. at 218,397 P.2d at 566.

153 Id.

154 This result is consistent with People v. Rodriguez, 11 N.Y.2d 279, 183 N.E.2d 651, 229 N.Y.S.2d 353 (1962), where, after being confronted with a gun and several other objects claimed to be illegally seized, the defendant confessed. Accord, United States v. Nilkrasch, 367 F.2d 740 (7th Cir. 1966); People v. Stoner, 65 Cal. 2d 595, 422 P.2d 585, 55 Cal. Rptr. 897 (1967). See also Commonwealth v. Spofford, 343 Mass. 703, 180 N.E.2d 673 (1962). But see People v. Chennault, 20 N.Y.2d 518, 232 N.E.2d 324, 285 N.Y.S.2d 289 (1967). 
confrontation by illegally obtained evidence or knowledge of its seizure. Even assuming that evidence is lawfully obtained, the suspect cannot be confronted with it until after he has waived his rights. A waiver following such a confrontation would not be the product of a rational intellect and free will. ${ }^{165}$ If, however, the police advised the suspect that the evidence had been illegally seized and neither it nor its fruits could be used against him, then a subsequent waiver after knowledge of the illegal search might well be valid.

After establishing the initial illegality and the confrontation, the burden of proof should shift to the prosecution to establish that the confession or admission was not induced by the confrontation. ${ }^{160}$ However, Fahy indicates that the burden of proof is on the defendant, holding that the accused should have an opportunity to establish that the confession was induced by the illegally seized evidence. In this situation, the burden of proof question is somewhat academic, for as a matter of common sense it is difficult to come to a result other than that the confession was induced by the evidence.

Since confronting a suspect with evidence-legally or illegally obtained-is a subtle method of interrogation, ${ }^{157}$ it appears necessary and desirable to give the defendant a Miranda warning to assure that his response is not "compelled." This could be best accomplished, as suggested by the Attorney General of California, immediately upon arrest. ${ }^{158}$ If a warning were immediately given to the accused and valid waiver obtained before the accused was told of legally seized evidence, subsequent admissions or confessions would be sound.

Costello v. United States, ${ }^{159}$ discussed above, implied that if admissions before the grand jury were induced by the belief that the prosecutor already had the desired answers as the result of illegally obtained evidence, the admissions would be inadmissible. The discussion of Kitashiro and Fahy lends support to sucli a reading. ${ }^{160}$ Need the individual sub-

155 See Rothblatt and Pitler, supra note 116 , at $490-91$.

150 The court in Kitashiro seems to adopt such a requirement. "Some evidence was required to rebut the natural and reasonable inference that the statement made by the police concerning the stolen parts taken from defendant's home had the intended effect on defendant and did induce his confession ... ." 48 Hawaii at 218, 397 P.2d at 566.

157 See Rothblatt and Pitler, supra note 116, at 486.

158 Lynch, Interrogation of Criminal Defendants-Some Views on Miranda v. Arizona, 35 Fordiax L. Rev. 221, 224 (1966).

169 Costello v. United States, 365 U.S. 265 (1961).

100 See United States v. Marrese, 336 F.2d 501 (3rd Cir. 1964), where the court indicates that a statement by defendant at police headquarters, after a search incident to an unlawful arrest, is the "fruit of the poisonous tree." See also Comnionwealth v. Spoffard, 343 Mass. 703, 180 N.E.2d 673 (1962). 
poenaed before the grand jury be aware that the prosecutor possesses evidence which connects him with some unlawful activity? ${ }^{101}$ Let us assume that by illegal wiretapping, a conversation concerning organized gambling between $X$ and $Y$ has been overheard. $X$ is called before the grand jury, is fully warned, and intelligently waives his rights. The district attorney asks questions based on the illegally "seized" conversations, procuring several damaging admissions. $X$ is indicted, and at trial the prosecution seeks to introduce these admissions. By this time defense counsel has discovered the fact of electronic surveillance and seeks to suppress the statements as "fruits of the poisonous tree."

Although $X$ 's answers were induced by the questions, they were not induced by knowledge of damaging evidence in the hands of the district attorney. There has been no fifth amendment violation, and the only objection to be made must either be based on the fourth amendment or a statutory violation. Clearly, the illegally obtained evidence was used to frame the questions. But for this evidence the questions would never have been asked, and in all likelihood the admissions never made. Of course, under Wong Sun this is not enougl. The illegality has certainly been exploited, but the answers have been gained through the individual's independent decision to speak, and are probably admissible.

The same situation may take place in the stationhouse after a waiver of the Miranda rights. The questioning may take place in the presence of counsel. These knowledgeable questions may convince the lawyer that the case is hopeless, and he may advise his client to cooperate. However, in such a situation the client has in fact been "induced" to cooperate because of the illegally seized evidence. If, in answering these questions, the suspect gives damaging evidence against himself but does not cooperate, the statements are currently admissible. ${ }^{162}$

There is also another possibility. A witness is called before the grand jury, invokes his fifth amendment privilege, is granted immunity, still

$161 \mathrm{~A}$ more common occurrence is when questions of a witness at trial are based on illegally seized evidence. In a situation where the court found an independent source for the questions, the opinion nevertheless indicated "[w] hat is seen and heard, even on an illegal entry, may be made the basis of a questioning for evidence." Warren v. Hawaii, 119 F.2d 936, 938 (9th Cir. 1941), relying on Olmstead v. United States, 277 U.S. 438 (1928). A close reading of Olnstead, however, reveals nothing that would justify such rehance.

162 In Hollingsworth v. United States, 321 F.2d 342, 351-52 (10th Cir. 1963), the court found in a well-considered dictum that questions propounded to the defendant, based on knowedge obtained from an illegal search and seizure, and defendant's answers thereto which were excluded by the trial court, would have been admissible only because the questions were based on an independent source. Cf. Commonwealth v. Spofford, 343 Mass. 703, 180 N.E.2d 673 (1962), where the court indicated that in a stationhouse setting, the questioning "received impetus from the improperly acquired material. . .." Id. at 708, 180 N.E.2d at 676. The defendant, however, was fully aware of the unlawful seizures. See also Wiggins v. United States, 64 F.2d 950, 951 (9th Cir. 1933). 
refuses to answer basing his refusal on the fourth amendment, and is in contempt and sentenced to jail. Is an individual, when granted immunity from prosecution, required to answer any and all questions regardless of the state's use of illegally obtained evidence to frame the question ? $^{163}$ The answer in all likelihood is yes, since there is immunity from prosecution and this should sufficiently remove the incentive for the unlawful "seizure" of conversations. It is possible that the prosecution will wiretap to discover prospective witnesses and then offer them immunity. If this practice become prevalent perhaps one should have a "privilege" not to answer such question to deter wiretapping.

However, the problem of the first and second hypotheticals lingers on, and the exploitation of the initial illegality, purged only by the independent decision to speak, still presents a clear incentive for illegal searches, wiretapping, and bugging. ${ }^{164}$ This incentive is clearly illustrated by the use of wiretapping in "inducing" potential defendants to cooperate and testify for the government in exchange for leniency and in some cases, immunity. The Second Circuit has held, however, that such testimony will be excluded, at least when the witness has been discovered by unlawful means, is "induced" to testify by playing the tapes to him, and has standing to object to the wiretapping. ${ }^{165}$ There is also very strong dicta indicating that the Supreme Court will exclude the testimony of any witness so induced, ${ }^{166}$ or at least when that testimony prejudices one who has standing to object to the wiretapping.

In order to deter official illegality, all statements induced by illicit police activity should be excluded regardless of the type of illegality involved. To be realistic, however, the continued existence of the standing requirement serves to encourage illicit eavesdropping and wiretapping, and the exclusion of evidence in certain narrow situations may not effectively deter such activity.

\section{B. The Confession as a Poisonous Tree $e^{167}$}

The Supreme Court has never held a confession to be a "poisonous

103 United States ex rel. Ciffo v. McClosky, 273 F. Supp. 604 (S.D.N.Y. 1967) answers this question in the affirmative. See Lanza v. New York, 370 U.S. 139, 145 (1962) where this question is left open.

164 See Broeder, supra note 132 , at 527.

105 United States v. Tane, 329 F.2d 848 (2d Cir. 1964).

100 Goldstein v. United States, 316 U.S. 114, 122 (1942). See also Weiss v. United States, 308 U.S. 321, 330 (1939).

167 Initially, coerced confessions were excluded because they were unreliable. The King v. Warickshall, 1 Leach Crown Cas. 298, 168 Eng. Rep. 234 (1783). The Supreme Court in the early coerced confession cases adopted this rationale. See Lisenba v. California, 314 U.S. 219, 236 (1941); Chambers v. Florida, 309 U.S. 227, 231 (1940). However, Rogers v. Rich- 
tree." Miranda ${ }^{188}$ did not explicitly concern itself with the fruits of a confession obtained absent the required warnings. However, in Westover v. United States ${ }^{169}$ the Court examined the admissibility of the fruit of an illegal interrogation-a waiver. In that case, the defendant had been extensively interrogated by local police for some fourteen hours although never informed of his rights. He was then turned over to the FBI, which, after warning him of his rights, pursued a new line of questioning in the same local police headquarters. The defendant subsequently confessed. The Supreme Court held the confession inadmissible because the

mond, 365 U.S. 534 (1961), made explicit what had long been implicit-that involuntary confessions were excluded:

not because such confessions are unlikely to be true but because the inethods used to extract them offend an underlying principle in the enforcement of our criminal law; that ours is an accusatorial and not an inquisitorial system-a system in which the State must establish guilt by evidence independently and freely secured and may not by coercion prove its charge against an accused out of his own mouth.

Id. at 540. See W. RicHardson, Evmence \$ 543a (6th ed. 1964); Allen, Due Process and State Criminal Procedure: Another Look, 48 Nw. U.L. REv. 16, 19-22 (1953); Kamisar, What is an "Involuntary" Confession? Some Comments on Inbau and Reid's "Criminal Interrogation and Confessions," 17 RUTGERs L. REv. 728, 741, 747-55 (1963).

It is doubtful whether initially the constitutional underpinning for the exclusion of involuntary confessions in the federal courts was the fifth amendment. See Ziang Sung Wan v. United States, 266 U.S. 1, 14 (1924); Powers v. United States, 223 U.S. 303, 313 (1912). But see Bram v. United States, 168 U.S. 532, 542 (1897). See also McCormick, The Scope of Privilege in the Law of Evidence, 16 TExas L. REv. 447, 453 (1938). Those Court decisions which excluded involuntary confessions in state cases were apparently based on a generic concept of due process. See, e.g., Stein v. New York, 346 U.S. 156 (1953); Watts v. Indiana, 338 U.S. 49 (1949); Brown v. Mississippi, 297 U.S. 278 (1936). However, first in Malloy v. Hogan, 378 U.S. 1 (1964), and then in Davis v. North Carolina, 384 U.S. 737 (1966), the Supreme Court left no doubt that the voluntariness standard was "grounded in the policies of the privilege against self-incrimination." Id. at 740 .

168384 U.S. 436 (1966). Chief Justice Warren in the majority opinion clearly indicates that "unless and until such warnings and waiver are demonstrated ... no evidence obtained as a result of interrogation can be used against [the defendant]." Id. at 479. Mr. Justice Clark, dissenting, wrote that "failure to follow the new procedures requires inexorably the exclusion of any statement by the accused, as well as the fruits thereof." Id. at 500. Mr. Justice Harlan's dissenting opinion also intimates that the fruits of a Miranda violation must be excluded. Id. at 522 . Only Mr. Justice White's dissenting opinion appears to indicate that the question renuains an open one. Id. at 526. However, see his concurring opinion in Murphy v. Waterfront Comm'n, 378 U.S. 52, 103 (1964). See also A. Specter \& M. Katz, Police Guide to Search and Seizure, Interrogation, and Confession 23 (1967).

It is true, however, that the majority opinion does not specifically enunciate a derivative evidence rule for confessions. See B. George, Constirutronal Lmitations on Evidence in Crnumai Cases 123 (1966). This same commentator suggests that such an important question cannot be said to have been decided in such a cursory manner and that the question, for the present at least, remains an open one. George, Interrogation of Criminal Defendants -Some Views on Miranda v. Arizona, 35 FordHaAr L. REv. 193 (1966). Contra, Cohen, Derivative Evidence-A Part of the Law of the Land, in A NEw Look AT Confesstons: Escobedo-The Second Round 135 (1967). Cf. W. Schaefer, The Suspect aNd Soctety 11 (1967).

168384 U.S. 436, 496 (1966). 
federal officers were the "beneficiaries of the pressure applied by the local in-custody interrogation." ${ }^{\text {"170 }}$ Under these circumstances there could be no assumption that the defendant had intelligently waived his riglits, and the Court found that the coercive atmosphere of the illegal local interrogation disabled the suspect from making a knowing and intelligent waiver.

The opinion stated that "[a] different case would be presented if an accused were taken into custody by the second authority, removed both in time and place from his original surroundings, and then adequately advised of his rights and given an opportunity to exercise them."171 This apparently would suffice to purge the evidence of its primary taint.

\section{Consecutive Confessions and Intelligent Waivers}

Assume that in a situation analogous to Westover the suspect is arrested, not warned of lis rights, questioned, and finally confesses. He is then brouglit before a committing magistrate who warns hin of his right to counsel and to remain silent, and finds probable cause to hold the defendant for action by the grand jury. Assume further that defendant cannot make bail and is returned to the jail. While in custody, a different police officer warns him of his rights; defendant waives and reaffirms his prior confession. ${ }^{172}$ It is clear that the initial confession violates Miranda and is inadmissible. What of the reaffirmation?

If the preliminary hearing is viewed as commencing the judicial stage of the proceedings, Massiah v. United States ${ }^{173}$ might operate to exclude the reaffirmation. Massiah held that once judicial proceedings were commenced-in this case, an indictment-against the accused, ${ }^{174}$ every state-

170 Id. at 497.

171 Id. at 496.

172 See Killough v. United States, 315 F.2d 241 (D.C. Cir. 1962).

173377 U.S. 201 (1964).

174. The New York rule which is the forerunner to Massiah held that the arraignmentfirst appearance before a committing magistrate commenced the judicial proceedings against the accused and required suppression of any statement obtained thereafter. People v. Waterman, 9 N.Y.2d 561, 175 N.E.2d 445, 216 N.Y.S.2d 70 (1961); People v. Di Biasi, 7 N.Y.2d 544, 166 N.E.2d 825, 200 N.X.S.2d 21 (1960). The rule is absolute so that an unsolicited statement to a police officer after arraignment will fall in its wake. People v. Meyer, 11 N.Y.2d 162, 182 N.E.2d 103, 227 N.Y.S.2d 427 (1962). This appears to be a rather mechanical application of the rule. See also People v. Rodriguez, 11 N.Y.2d 279, 183 N.E.2d 651, 229 N.Y.S.2d 353 (1962) (statements held inadmissible during an adjournment of the arraignment). See generally W. RICHARDSON, supra note $167, \S 533 \mathrm{c}$. The judicial stage bas also been extended to the filing of an information. People v. Bodie, 16 N.Y.2d 275, 213 N.E.2d 441, 266 N.Y.S.2d 104 (1965).

The vitality of postjudicial stage distinction was apparently continued in the recent lineup cases before the Court. Mr. Justice Brennan in United States v. Wade, 388 U.S. 218 (1967), continually stresses the fact that the case concerns a "post-imdictment" lineup. The Court relies on the reliability factor of lineups as requiring appointment of counsel. Exactly 
ment of the accused obtained in the absence of counsel thereafter must be suppressed. If there was no warning before the reaffirmation, and a police officer disguised as a cellmate obtained the incriminating statement, it is clear that Massiah would require the statement's exclusion. ${ }^{175}$ On the other hand, Massiah involved special facts, and there is a paucity of authority concerning waiver of postjudicial-stage rights. ${ }^{170}$

In People v. Bodie, ${ }^{177}$ a pre-Miranda decision, the filing of an information was held to commence the judicial proceedings. Upon arrest the defendant was asked if he desired counsel, and the same question was asked upon arrival at police barracks. To both of these questions he answered "no." Bodie had a criminal background, and a majority of the court found that he understood "the officer's statement and knowingly waived his right to counsel."178

The dissenting opinion of Judge Fuld concedes that the right to counsel may be waived, but only after the defendant has been arraigned in court and advised of his rights" ${ }^{179}$ "or until he has, at least, consulted with a lawyer." 180 In conclusion, Judge Fuld argued for a rule that would, after judicial proceedings have been commenced, prohibit the accused from waiving his riglits unless he has appeared before and been warned by a judicial officer. Imphicit in this opinion is that after appearing before a committing magistrate and after a police warning, the accused may elect to answer questions.

A strong case can be made for the proposition that when the judicial

how a postindictment lineup is any different than a preindictment lineup in respect to reliability is difficult to ascertain.

175 People v. Miller, 245 Cal. App. 2d 112, 53 Cal. Rptr. 720 (1966), concerns the problem of an undercover agent in an adjacent cell. It is unclear whether the conversations with the agent took place after indictment, but the court's opinion appears to indicate that they at least took place subsequent to arraignment. Id. at $143-44,53$ Cal. Rptr. at 740. At the trial the agent took the stand and testified about the conversations. The appellate court condernned the practice but found that there was nothing prejudicial in the agent's testimony. The Supreme Court has agreed to review the decision. Miller v. California, 389 U.S. 968 (1967).

${ }^{178}$ The right to counsel at a postindictment hneup nnay be waived. United States v. Wade, 388 U.S. 218, 237 (1967). Whether a suspect may waive something he is privileged from doimg, such as confessing, is another question.

17716 N.Y.2d 275, 213 N.E.2d 441, 266 N.Y.S.2d 104 (1965).

178 Id. at 279,213 N.E.2d at 443,266 N.Y.S.2d at 107. Under Miranda, the warnings Inust be given to each individual regardless of the probability that he is aware of his rights. Miranda v. Arizona, 384 U.S. 436, 469 (1966). It appears reasonable, however, to consider the suspect's degree of criminal sophistication in determining the intelligence of the waiver.

179 Compare Wade v. United States, 358 F.2d 557 (5th Cir.), modified, 388 U.S. 293 (1967) with Stovall v. Deuno, 355 F.2d 731 (2d Cir.) (ent banc), af'd, 388 U.S. 293 (1967). Both of these cases concern the propriety of a lineup after counsel was or should have been appointed and the subsequent testimony concerning an identification at that lineup.

180 People v. Bodie, 16 N.X.2d 275, 280, 213 N.E.2d 441, 444, 260 N.Y.S.2d 104, 108 (1965). 
stage of a criminal prosecution has been reached, we are in the adversary phase of the criminal prosecution, and the question of whether to submit to interrogation can be answered by the accused only after consultation with his lawyer. The Miranda warnings were estabhshed in hight of prejudicial-stage interrogation and the privilege against self-incrimination. The Court in Miranda does not cite Massiah, which was based solely on the sixth amendment's right to counsel. ${ }^{181}$

It could very well be that after the cominencement of the judical stage, the prosecution will be forbidden access to the defendant without going through his attorney. ${ }^{182}$ In seeking to interrogate a defendant after arraignment in quest of a confession or admission, the police certainly "become, in a very real sense, his 'adversaries', allied with the prosecution, in an effort to support the charge already laid against him." ${ }^{183}$ When a suspect is questioned after arrest, such interrogation may be for the purposes of determining whether to charge him with a crime. Once the judicial stage is reached, the only purpose of interrogation is to obtain incriminating statements. In effect, the adversary proceeding has commenced and

[a] lawyer should not in any way communicate upon the subject of controversy with a party represented by counsel; much less should he undertake to negotiate or compromise the matter with him, but should deal only with his counsel. It is incumbent upon the lawyer most particularly to avoid everything that may tend to mislead a party not represented by counsel, and he should not undertake to advise him as to the law. ${ }^{184}$

It would seem, however, that not all contact between the accused and the state should be forbidden, but rather only activity whicl the accused

181 See Graham, supre note 123, at 76.

182 The right to counsel at a postindictment lineup may be waived. United States $v$. Wade, 388 U.S. 218, 237 (1967). If a suspect after indictment attempts to waive his privilege against self-incrimination, then Massiah is considerably troublesome. Escobedo v. Ilinois, 378 U.S. 478 (1964), held that under certain circumstances when a police investigation "focused" on an accused, a confession obtained in the absence of counsel would be inadmissible. The term "focused" was redefined in Miranda as meaning police custody. 384 U.S. at 444. The rule now appears to be that a suspect in police custody after indictment may waive his rights in the same manner as authorized by Miranda. Unlike Miranda, however, a defendant after indictment may not be subjected to surreptitious questioming. It is difficult to understand exactly why such a distinction should exist. There either should be no waiver permitted after indictment or a fully parallel rule for both prejudicial or postjudicial interrogation.

183 People v. Bodie, 16 N.Y.2d 275, 281, 213 N.E.2d 441, 444, 266 N.Y.S.2d 104, 109 (1965) (dissenting opinion).

184 abA Canons of Professional Etmas No. 9, quoted with approval in Escobedo v. Illinois, 378 U.S. 478, 487 n.7 (1964). See Wade v. United States, 358 F.2d 557 (5th Cir. 1967); cf. Lee v. United States, 322 F.2d 770, 777 (5th Cir. 1963). 
is privileged not to do-consenting to a search, ${ }^{185}$ answering questions, ${ }^{180}$ or reenacting the crime. Of course, one could argue that the prosecution could delay the indictment. However, the preliminary examination commences the judicial stage, and this must be done without unnecessary delay. But, perlıaps Massiah was only a midstream approach ${ }^{187}$ and has been replaced by Miranda so that the right counsel can be waived through the Miranda system of warnings. ${ }^{188}$

Totally separate and distinct from Massiah is the problem of whether the reaffirmation-in our hypothetical - of the illegal confession is a "fruit of the poisonous tree." In United States v. Bayer ${ }^{180}$ the defendant, a soldier, was illegally induced to confess a crime. Some six months after the first confession he was called in by the FBI and warned of his right to remain silent. His earher confession was read to him, and he then confessed a second time. The Second Circuit found the second confession to be "patently the fruit of the earher one"150 and held it inadmissible, citing Silverthorne and Nardone. However, the Supreme Court reversed, stating that:

[A]fter an accused has once let the cat out of the bag by confessing no matter what the inducement, he is never thereafter free of the psychological and practical disadvantages of having confessed. He can never get the cat back in the bag. The secret is out for good. In such a sense, a later confession always may be looked upon as fruit of the first. But this Court has never gone so far as to hold that making a confession under circumstances which preclude its use, perpetually disables the confessor from making a usable one after those conditions have been removed. ${ }^{191}$

Thus, Justice Jackson, writing for the Court, found the confession admissible, closing with a citation to Lyons v. Oklahoma, ${ }^{192}$ whicl establishes

185 See A New Look at Confessions 105-06 (1967); Note, 67 Colus. L. Rev. 130 (1967).

186 See Schmerber v. Califormia, 384 U.S. 757, 766 (1966); L. HaIL and Y. KaMmsar, Modern Crmminal Procedure 485 n.1 (1966). But see Wade v. United States, 358 F.2d 557, 559-60 (5th Cir. 1967).

187 Although Massiah may not retain any validity in postindictment situations with the defendant being warned of his rights, it still retains vitality in situations without such a warning. In Beatty v. United States, 389 U.S. 45 (1967) (per curiam), decided subsequent to Miranda, the Court reversed by merely citing Massich.

188 See Kamisar, Some Comments on the "New" Fifth Amendment in Proceediscs, Eighteenth Annual Meeting of the Conferences of Chief Justices 35, 42-46 (1966). The judicial stage concept has been criticized as being formalistic as well as unrealistic. See People v. Garner, 57 Cal. 2d 135, 157-66, 367 P.2d 680, 693-99, 18 Cal. Rptr. 40, 53-59 (1961) (Traynor, C.J., concurring). See also Herman, The Supreme Coutt and Restrictions on Police Interrogation, 25 Orio Sr. L. J. 449, 491 (1964).

189331 U.S. 532 (1947).

190 United States v. Bayer, 156 F.2d 964, 970 (1946).

101 United States v. Bayer, 331 U.S. 532, 540-41 (1947).

102322 U.S. 596 (1944). 
the standard by which the admissibility of a second confession is to be judged: ${ }^{193}$ Have the coercive influences which caused the initial involuntary confession been removed or do they remain to make the subsequent confession involuntary as well?

If intensive interrogation during a fourteen hour period without a confession as in Westover is found to vitiate a subsequent waiver, are we also to conclude that, had the accused confessed, a subsequent waiver after warnings would be measured by whether the coercive elements which procured the first confession are still present? This would in effect undermine Miranda, for police could procure a confession absent the warnings, then take the suspect out for dinner, let him shower, shave, get a good twelve hours sleep, and the next day let two different officers warn and question him. The questioning need not even refer tangentially to the previous confession; for the suspect has those spoken words imprinted on his mind and assumes they can be used against him. Under such circumstances is any waiver the product of a free will and a rational intellect? ${ }^{194}$

A suspect who confesses is not perpetually disabled from confessing again. If he is made aware of the inadmissibility of the initial confession or has consulted with counsel who has so advised him, he may, nevertheless, conclude that it would be in his best interest to confess. Therefore, there appears no logical reason to treat the consecutive confession, or the confession as the fruit of other evidence, any differently than the problems of Nardone and Silverthorne.

\section{Suggested Solution}

The committing magistrate should be informed whether the suspect has confessed. Whether or not he is so informed the magistrate should caution the accused-in terms calculated to impress the layman-that (1) a confession and its fruits may, in certain situations, be unusable and (2) that the accused should inform and consult his attorney-retained or appointed-about any confession. ${ }^{195}$ If there is no absolute postjudicial

183 See also Leyra v. Denno, 347 U.S. 556 (1954); Stroble v. California, 343 U.S. 181 (1952); Malinski v. New York, 324 U.S. 401 (1945).

194 See Rothblatt and Pitler, supra note 9, at 490-91. The Eighth Circuit excluded a confession obtained by a federal agent after state officials had already obtained a confession. Evans v. United States, 375 F.2d 355 (8th Cir. 1967). Cf. Note, 74 HARv. L. Rev. 1222, 1223 (1961).

105 One student Note suggests that perhaps the magistrate ask the accused whether he had confessed. If the answer is affirmative then the magistrate would warn the accused about the possibility of the confession's inadmissibility and for the suspect to be careful durnig any further conversations. Note, 72 YALE L.J. 1434, 1453 (1960). The same Note, however, finds that an affirmative answer to such a question in a court of law inay have even a more devastating effect on the suspect. Id. 
right to counsel, the police may attempt to question the accused provided a valid waiver is obtained.

If it later develops that the first confession was invalid, a subsequent confession should be inadmissible absent a showing that the accused had consulted with a lawyer and the latter was aware of the initial confession. Assuming that no absolute right to counsel exists after the commencement of judicial proceedings, should the right exist after a confession has been obtained? The police have secured a waiver, commenced interrogation, and obtained their desired result. If anything else need be done with the accused, why should not access be controlled by counsel?

The impact of the initial confession or the method of interrogation after waiver may convince the accused that counsel is unnecessary, and he may decide to plead guilty. Under such circumstances a waiver of counsel and a guilty plea should be permitted only after consultation with counsel-retained or appointed-who must be informed of the confession. ${ }^{100}$

Since the Miranda Court was willing to rely on police warnings, ${ }^{107}$ the question arises whether police warnings of possible or actual exclusion will suffice? Miranda was predicated on the absence of prior unlawful police activity which would pressure the accused to waive his rights or cause the court to lose confidence in police warnings. In Westover the Court found a previous interrogation-absent a confession-vitiated a subsequent waiver. If, in procuring the first confession the police have violated Miranda, why should they be entitled to a "second shot" at the accused? An "admissibility" warning by the police after an initial confession, absent consultation with a lawyer, would have a negligible impact on the suspect. And the opportunity for the "second shot" would only serve to discourage comphance with Miranda to facilitate procurement of a second confession.

In any event, the burden of proof beyond a reasonable doubt ${ }^{108}$ is on the prosecution to establish that the psychological pressure exerted by the initial confession was sufficiently removed so that the subsequent waiver and confession resulted from means sufficiently distinguishable

108 It has been suggested that if a defendant has elected to plead guilty, he should not be permitted to waive counsel. Note, 112 U. PA. I. REv. 865, 889 (1964). Surely, where a prior confession may be the basis of the plea, an even stronger case for consultation with counsel is made.

107 See Rothblatt and Pitler, supra note 92, at 494-96.

108 Although most of the cases state that the burden rests on the prosecution, it appears as though they may speak of a somewhat lesser standard. See Note, 1963 Wis. L. REV. 674, 683 and cases cited in n.45. However, because Jackson v. Denno, 378 U.S. 368 (1964) apparently required the voluntariness of a confession to be established beyond a reasonable doubt, see People v. Huntley, 15 N.Y.2d 72, 204 N.E.2d 179, 255 N.Y.S.2d 838 (1965), and Miranda placed a very heavy burden on the prosecution to establish waiver, 384 U.S. 436, 475 (1966), it would seem reasonable to conclude that proof beyond a reasonable doubt would be required. 
from the initial confession. The nuagistrate's warning, when considered with the circumstances surrounding the confessions, must establish the dissipation of the primary taint. ${ }^{199}$

Hopefully police will adhere steadfastly to Miranda so that the problems of consecutive confessions will not frequently arise. If it happens, however, that such problems arise with great regularity, it would be unfortunate to return to a "totality of the circumstances" criteria. ${ }^{200}$

Since 1954 the field of criminal procedure has undergone considerable change-including Wong Sun and Miranda. The New York Court of Appeals extended its own Massiah rule to cover the fruits of such a violation, ${ }^{201}$ and the California supreme court recognized that the fruit of the poisonous tree doctrine was applicable to a confession obtained after failing to warn the suspect of his right to counsel. ${ }^{202}$ There appears no logical reason to permit the fruits of a Miranda violation to be admissible. Any other holding, despite the cries of the disastrous effects on law enforcement, ${ }^{203}$ would emasculate the rights granted by Miranda.

\section{The Fifth Amendment}

One need not argue by analogy to the search and seizure language of the "fruit of the poisonous tree" doctrine to apply it to a Miranda violation. Miranda is based on the fifth amendment's privilege against selfincrimination, and a body of law has developed regarding the fruits of such violations which makes it even nore emphatic that the "fruit of the poisonous tree" is applicable.

In Counselman v. Hitchcock, ${ }^{204}$ the fifth amendment was held to protect "against that use of compelled testimony which consists in gaining therefrom a knowledge of the details of the crime, and of sources of information which may supply other means of convicting the witness or party." chain of evidence needed to prosecute" or whether there is "an independent legitimate source for the evidence"206 - namely a source other than the "compelled" confession or admission. ${ }^{207}$

100 See Note, 73 YALE L.J. 1434, 1455-56 (1963).

200 See Kamisar, $A$ Dissent from the Miranda Dissents: Some Comments on the "New" Fifth Amendment and the Old "Voluntariness" Test, 65 MicE. L. Rev. 59, 94-104 (1966). 201 People v. Robinson, 13 N.Y.2d 296, 196 N.E.2d 261, 246 N.Y.S.2d 623 (1963). 202 People v. Buchanan, 63 Cal. 2d 880, 409 P.2d 957, 48 Cal. Rptr. 733 (1966). See also W. Scraefer, THe SUSRect and Soctety 11 (1967).

203 B. George, Constitutional lumtitions on Evmence in Crtaminal Cases 193 (1966).

204142 U.S. 547 (1892).

$205 I d$. at 586.

206 Hoffman v. United States, 34I U.S. 479, 486 (1951).

$207 I d$. 
Application of the derivative evidence rule leaves the suspect in substantially the same position as if he had been advised of his rights and exercised his privilege against self-incrimination. ${ }^{208}$ It has been suggested that a reading of Murphy v. Waterfront Commission ${ }^{200}$ indicates that a "but for" test applies when deahing with violations of the privilege against self-incrimination. ${ }^{210}$ Thus, in cases of fifth amendment violations there will be no "attenuation limitation." This imterpretation "may stem from the fact that under the fifth amendment the right not ... 'to be a witness' by itself requires exclusion, whereas exclusion based on the fourth amendment is merely an ancillary right designed to deter violations of the basic riglit of privacy."211 A literal reading of Counselman and Murphy supports such an analysis. The rationale of these cases is to assure that the state has no possible interest in compelling evidence from the individual.

It is difficult to avoid the conclusion, after a close reading of Miranda in light of the Court's thirty-year struggle with this problem, that although the conceptual underpinning of the confession rules may have been altered in Miranda, the Court's concern with, and determination to deter objectionable police interrogation methods has not abated. ${ }^{212}$ If, however, Miranda is viewed as an a priori decision holding that the individual is being granted a "new" fifth amendment right and that the privilege against self-incrimination is couched in terms of an "absolute riglit,"

Whether we adopt the deterrence view or the "strict" fifth amendment approacli it is clear that if the police were permitted to utilize illegally obtained confessions for links and leads rather than being required to gather evidence independently, then the Miranda warnings would be of no value in protecting the privilege against self-incrimination. ${ }^{214}$ The requirement of a warming would be meaningless, for the police would be permitted to accomplish indirectly what they could not accomplish directly, and there would exist no incentive to warn. ${ }^{215}$

208 Murphy v. Waterfront Comm'n, 378 U.S. 52, 79 (1964).

200378 U.S. 52 (1964).

210 Note, 114 U. PA. I. REv. 570, 576-77 (1966).

211 Developments in the Law-Confessions, 79 HARv. L. REv. 935, 1028 n.21. (1966).

212 See generally W. Lockhart, Y. KaMmsar \& J. CHToper, Constitumonat LAW CAses-Comanents-Questions 653-56 (2d ed. 1967) and authorities collected therein.

213 Cf. id.; Note, 42 N.Y.U.L. REv. 772, 777-78 (1967).

214 See Nedrud, The New Fifth Amendment Concept: Self-incrimination Redefined, 2 NAT'x DisT. ATr'ys Ass'N J. 112, 114 (1966); Pye, supra note 168, at 218-19. See generally Note, 6 WASHBURN L.J. 133 (1966).

215 See Rothblatt and Pitier, supra note 92, at 489. 
v

\section{EXCEPTIONS TO THE EXCLUSIONARY RULE}

\section{A. Witnesses as the Fruit of the Poisonous Tree}

When tangible evidence is found after its location is disclosed through an illegally obtained confession, an unlawfully installed "bug," or any other "tainted source," there is little reason to view the evidence as anything other than the "fruit of the poisonous tree." If, on the other hand, the police break into the office of a suspected abortionist, seize his files and discover the names of possible witnesses, the exclusion of such witnesses poses a more difficult problem. Judges are understandably reluctant to exclude reliable evidence, and there appears to be a visceral reaction to excluding a witness merely because his identity lias been disclosed by an illegal source. ${ }^{216}$ It is clear that the police have exploited the primary illegality to procure evidence, but is the witness' subsequent testimony sufficiently separate and distinct from the initial illegality to permit its introduction? Some courts have considered the problem in this context. The more cogent question is, however, whether the exclusion of such witnesses is necessary to deter official illegality.

In Smith and Bowden v. United States, ${ }^{217}$ the court refused to exclude the testimony of a witness whose identity had been revealed by a confession obtained in violation of Federal Rule of Criminal Procedure 5(a). ${ }^{218}$ After the police located the witness, he refused to testify at a coroner's liearing or before the grand jury. ${ }^{219}$ Finally, after grappling with his conscience, the witness decided to testify at trial. ${ }^{220}$ The court ruled that, under these facts, the prosecution could use a live witness discovered through an illegally obtained confession. ${ }^{221}$ The court distinguisled Wong Sun as requiring the exclusion of tangible evidence and statements of the appellant.

In Wong Sun, the statements of $A$ led to $B$, who removed narcotics

216 For the approach of two trial judges, see People v. Dannic, 52 Misc. 2d 1012, 277 N.Y.S.2d 331 (Sup. Ct. 1967), and People v. Scharfstein, 52 Misc. 2d 976, 277 N.Y.S.2d 516 (Sup. Ct. 1967).

217324 F.2d 879 (D.C. Cir. 1963).

218 The witness' identity was initially disclosed by one of the defendants, whose age at the time brought him within the jurisdiction of the juvenile court. The District of Columbia Circuit has, however, interpreted its Juvenile Court Act, D.C. Code Ann. §§ 11-90ל, 11-914 (1961), to require the exclusion in criminal court of the confession of an individual who is within the juvenile court's jurisdiction, when that court subsequently waives jurisdiction. Harling v. United States, 295 F.2d 161 (D.C. Cir. 1961) (en banc).

219 These facts are not indicated by the Smith and Bowden decision, but are brought out in McLindon v. United States, 329 F.2d 238, 241 n.2 (D.C. Cir. 1964).

$220 I d$.

221 Smith and Bowden v. United States, 324 F.2d 879, 881 n.2 (D.C. Cir. 1963). 
from the drawer and gave it to the authorities. The narcotics were not discovered until a human being decided to turn over the drugs. ${ }^{222}$ The Supreme Court did not consider whether this "deliberate act" was sufficient to "purge the taint" of using A's statement to find the narcotics. Of course, Wong Sun could be further distinguished in that $B$ 's decision to turn over the drugs was not voluntary. $B$ was under arrest, and it was obvious that the police were going to conduct an incidental search which would have inevitably turned up the drugs. Hence their production was more under the "compulsion" of the arrest than any independent, reflective determination as inade by the witness in Smith. ${ }^{23}$

The Smith and Bowden court could not find any decision requiring the exclusion of a witness discovered through a Rule 5 (a) violation, but failed to mention People v. Martin, ${ }^{224}$ which excluded witnesses discovered through the unlawful seizure and examination of private papers. It also appears to have overlooked People v. Albea, ${ }^{225}$ which excluded testimony of a witness discovered after illegally entering a doctor's office. ${ }^{226}$ However, in these situations there was no evidence of the witness' initial reluctance. Smith and Anderson v. United States, ${ }^{227}$ a later case decided by the Smith and Bowden court, apparently maintains the vitality of that distinction.

During an unlawful search of appellant's car, the police marked down the serial number of a transmission they found in the trunk. After learning that the transmission had been stolen, they returned with a search

222 See id. at 884 n.6 (Bazelon, C.J., dissenting).

223 Assume an illegally obtained confession reveals the location of a gun which is established by a ballistics expert to be the murder weapon. Since the expert witness is an individual personality who will determine what testimony he will give, is he permitted to testify about his findings although the gun itself is not admissible? The Smith and Bowden opinion would not mandate this result because the testinony of the ballistics expert would, of necessity, be based on the illegally seized gun, while the testimony of the witness would in no way be dependent upon the illegally obtained confession. Cf. Fahy v. Connecticut, 375 U.S. 85,89 (1963).

224382 IIl. 192, 46 N.E.2d 997 (1942). Accord, People v. Mickelson, 59 Cal. 2d 448, 380 P.2d 658, 30 Cal. Rptr. 18 (1963); People v. Schaumloffel, 53 Cal. 2d 96, 346 P.2d 393 (1959); People v. Mills, 148 Cal. App. 2d 392, 306 P.2d 1005 (1957); People v. Schmoll, 383 III. 280, 48 N.E.2d 933 (1943); Abbott v. United States, 138 A.2d 485 (D.C. Mun. Ct. App. 1958). Contra, People v. Eddy, 349 Mich. 637, 85 N.W.2d 117 (1957), cert. denied, 356 U.S. 918 (1958). In the latter case the identity of several witnesses was brought to hight through the examination of illegally seized records. The factual situation is almost identical to People v. Martin, supra. The court, however, was unable to find any authority to exclude witnesses found by such methods and the testimony was held admissible.

2252 IIl. $2 \mathrm{~d} 317,118$ N.E.2d 277 (1954).

226 Compare State v. O'Bremski, 423 P.2d 530 (Wash. 1967), where the police alrendy knew the existence and identity of a witness they found on the premises of an apartunent they entered illegally.

227344 F.2d 545 (D.C. Cir. 1965). 
warrant, but the transmission was gone. The police questioned the appellant, who told them that he had sold the transmission to one Dean. After being located by the officers, Dean stated that he had sold the transmission to Donaldson and Hardy and gave them Donaldson's address. A detective telephoned Donaldson's father, who told his son of the conversation. Donaldson called Hardy, told him the transmission was stolen and mistakenly told him that the police did not have his name. Nevertheless, Hardy decided to take the transmission to the police. He did this on the next day, and the transmission was the one seen by the police during the illegal search.

Both Hardy and Donaldson were permitted to testify at appellant's trial, the trial judge holding the testimony "too attenuated to the [illegal] discovery of this transmission . . . "228 The District of Columbia Circuit disagreed, finding that the police had used the knowledge derived from the unlawful searcli to find that the transmission was stolen and that it was ultimately sold to Donaldson and Hardy. The fact that the police only contacted Donaldson and that Hardy was misinformed as to the police's knowledge of him was not sufficient to remove the police-created pressure which ultimately impelled Hardy to turn the transmission over to the police. "[A]lthough several 'human personalities intervened between illegal discovery of the transmission and the testimony of Hardy and Donaldson ...."2229 there was no resistance nor reluctance on the part of the witness to speak. "The road from the [illegal source] to the testimony may be long, but it is straight." "230

One may seriously question whether there is any real distinction between the two Smith cases. ${ }^{231}$ In any event the "initial reluctance" test appears very difficult to administer. ${ }^{232}$ After the police find the witness, may they "persuade" hin to speak? Is the method of persuasion a factor ${ }^{233}$ How are the real reasons underlying the witness' decision to speak discovered?

There is, however, another test, proposed by the District of Columbia Circuit to be used when dealing with the discovery of a witness through the use of illegally obtained evidence. This test requires an examination

228 Id. at 547 .

220 Id.

280 Id.

231 But see The United States Court of Appeals for the District of Columbia Circuit: 1964-65 Term, 54 GEo. L. Rev. 185, 225-28 (1965), where the authors suggest that a court must assess the "attributes of 'will, perception, memory and volition' to determine if they constitute a break in the chain from illegality to fruit." Id. at 228.

232 Cf. Hawkins v. United States, 358 U.S. 74, 81-83 (1958) (concurring opinion).

233 If the witness is persuaded to testify by wiretaps or other evidence to which defendant has standing to object, then the witness' testimony will not be admissible. United States v. Tane, 329 F.2d 848 (2d Cir. 1964). 
of all of the relevant circumstances to determine "how great a part the particular manifestation of 'individual human personality' played in the ultimate receipt of the testimony in question." persuasion" are apparently irrelevant in applying this standard, ${ }^{235}$ and it appears that the "more persuasion" necessary the more "attenuated" the testimony.

In the first Smith case, the reluctance of the witness to testify not only at the coroner's hearing but also before the grand jury was apparently sufficient "attenuation" of the initial illegality for the court to include the testimony. ${ }^{236}$ Assuming that the witness would not have been found "but for" the illegality, the individual's struggle with his conscience has allegedly "purged the taint" of the police exploitation of the illegal confession. The court, however, failed to consider that the police did, in fact, exploit the illegality by using the confession to trace and locate the witness. The individual's decision to speak should not alter the fact that his discovery has been obtained by the use of illegally obtained evidence.

Once we focus on the relevant criteria, we will have gone a long way toward making analysis both tractable and serviceable to the deterrent ends of exclusionary rules by carefully defining what the inquiry should at most consist of; not useless inquiries as to the will or responsibibty of the witness whose utterances are in question, but an inquiry directed solely at the responsibility of the prosecution and its agents for turning up that evidence-an inquiry that asks if the prosecution exploited the improper conduct of which it was guilty. ${ }^{237}$

No distinction remains, if ever one existed, between tangible evidence and "live" witnesses when determining what is, or is not, the fruit of the poisonous tree. ${ }^{238}$ Any other result is inconsistent with the deterrence rationale of the "fruit of the poisonous tree" doctrine. ${ }^{230}$

\section{B. The Independent Source Rule}

As has been previously indicated, the "fruit of the poisonous tree" doctrine "has no application when the Government learns of the evidence

234 McLindon v. United States, 329 F.2d 238, 241 n.2 (D.C. Cir. 1964).

235 'Indications in the record that mere knowledge of the witness' identity would not inevitably guarantee that his testimony would be favorable to the prosecution; that the witness might eventually have voluntarily gone to the police even without their knowing his identity; that his testimony has remained unchanged from the start-all are relevant factors to be considered in determining the final outcome." Id.

236 See also Edwards v. United States, 330 F.2d 849 (D.C. Cir. 1964) where a witness at trial exculpated the defendants but when confronted with the story he told the police and his testimony before the grand jury, recanted and implicated the defendants.

237 See Ruffin, Out On A Limb Of The Poisonous Tree: The Tainted Witness, 15 U.C.L.A.L. REv. 32, 33 (1967).

238 Id. at 32. See Note, 30 N.Y.U.L. Rev. 1121, 1123 (1955); Note, 32 ChI.-Kent L. REV. 349, 350-51 (1954).

230 See People v. Albea, 2 III. 2d 317, 322, 118 N.E.2d 277, 279-80 (1954). 
from an independent source." ${ }^{240}$ In Bynum v. United States, ${ }^{241}$ fingerprints obtained from the defendant after his illegal arrest were held inadmissible. At the second trial, the government introduced a set of defendant's fingerprints obtained from FBI files. ${ }^{242}$ The court held these prints admissible, finding that they were obtained from an independent source, not as the result of exploitation of the primary illegality.

The government on the first appeal argued that the fingerprints could have been obtained from a legitimate source and that it was an exercise in futility to reverse and order a new trial. The court replied:

It is entirely irrelevant that it may be relatively easy for the government to prove guilt without using the product of the illegal detention. The important thing is that those administering the criminal law understand that they must do it that way. ${ }^{243}$

The court at the close of its opinion suggested that if the prosecution proceeded at the second trial without the tainted prints, no problem would arise.

The decision in the first Bynum case pushes the logic of the exclusionary rule to the extreme, and it may be too mechanical an application of the "fruit of the poisonous tree" doctrine. The expense, both in time and money, and the apparent futility of a second trial militate against such an application. On the other hand, the defendant has the right to a trial unencunibered by the introduction of constitutionally inadmissible evidence. The evidence in Bynum linked the defendant to the crime, and its introduction certainly cannot be considered harmless error. The court, however, approached the problem from the deterrence point of view and found the inconvenience of a second trial for the prosecution an effective means to curb similar conduct in the future.

In Commonwealth v. Nicholls, ${ }^{244}$ two police officers arrested three individuals. One of the officers opened the glove compartment of defendants' car, searching for a gun or other weapon. Instead he found certain articles of jewelry, but did not seize them. Meanwhile, the other officer returned to the police station, secured a search warrant, and in executing it found jewelry in both the glove compartment and trunk of the car. The jewelry turned out to be the fruits of a previously unreported burglary. The second police officer testified that he had no knowledge of the first officer's search of the automobile. The judge believed this testimony ${ }^{245}$

240 Wong Sun v. United States, 371 U.S. 471,487 (1963).

241262 F.2d 465 (D.C. Cir. 1958).

242 Bynunı v. United States, 274 F.2d 767 (D.C. Cir. 1960).

243 Bynum v. United States, 262 F.2d 465, 469 (D.C. Cir. 1958).

$244207 \mathrm{~Pa}$. Super. 410, 217 A.2d 768 (1966).

245 The testimony by itself is soniewhat incredible. It seems fair to assume that police officers from the same headquarters working on the same case at the same time, work together. Cf. Elkins v. United States, 364 U.S. 206, 211, 221 (1960); Davis v. North 
and found it unnecessary to determine whether the initial search was unlawful since the evidence had been gained from an independent source.

In both Bynum and Nicholls there were clearly two sources for the evidence in question. ${ }^{246}$ In both cases, the legal source was found after the knowledge of the evidence had been obtained from the tainted source. Bynum, however, involves a procedure which leaves no room for doubt that there is, in fact, an independent source. The facts of Nicholls, as was previously indicated, leave much to be desired. When the independent source exists, and it is known prior to the police illegality, then a stronger case for admission is presented. ${ }^{247}$ If the independent source is found to exist, or in fact comes into existence after the initial illegality, then it must be carefully examined ${ }^{248}$ in order to prevent the independent source requirement from becoming an "illusory source requirement."

The Bynum case is somewhat of a mutation in that the second set of fingerprints had a separate and independent existence and could have been lawfully obtained without using the prints taken during the illegal arrest. When a confession is obtained or evidence seized, there usually exists no duplicate to be fonnd without utilizing the knowledge obtained by the illegality.

Another independent source problem arises when the police have probable cause to arrest an individual, but, before arresting him and while awaiting his return home, make an unlawful search of the premises. The search reveals evidence establishing the guilt of the suspect. The evidence is left where it is found, and after the suspect enters his apartment, he is arrested. A search incidental to arrest then reveals what is already known to exist. ${ }^{249}$

If probable cause to arrest did in fact exist, then why was a search of the premises undertaken? Perhaps the police were overanxious, or

Carolina, 339 F.2d 770, 783 (4th Cir. 1964) (Sobeloff, J., dissenting), rev'd, 384 U.S. 737 (1966). But see United States v. Radford, 361 F.2d 777 (4th Cir. 1966).

246 For a case where it is clear that there is one source and it is tainted, sec People v. Robinson, 13 N.Y.S.2d 296, 196 N.E.2d 261, 246 N.Y.S.2d 623 (1963).

247 See United States v. Barrow, 363 F.2d 62, 66 (3d Cir. 1966), where a patron who was discovered on the premises during an illegal raid on a gambling casino was permitted to testify. The prosecution established that the witenss was a frequent visitor to the establishment whose identity had been known for some time prior to the unlawful entry. See also Weaver v. United States, 374 F.2d 878 (5th Cir. 1967) (dicta); Hollingsworth v. United States, 321 F.2d 342, 352 (10th Cir. 1963).

248 See United States v. Giglio, 263 F.2d 410 (2d Cir.), cert. denied, 361 U.S. 820 (1957); United States v. Sheba Bracelets, 248 F.2d 134, 141-42 (2d Cir. 1959), cert. denied, 355 U.S. 904 (1960).

249 Compare United States v. Ball, 8 U.S.C.M.A. 25, 23 C.M.R. 249 (1957), where under similar circumstances such evidence was said to be admissible, with Hurst v. California, 211 F. Supp. 387, 393 (ND. Cal. 1962), aff'd, 325 F.2d 891 (9th Cir. 1963), cert. dentied, 368 U.S. 843 (1964). 
perhaps the search was a tactic designed to assure that incriminating evidence would be found where the arrest was to be made. ${ }^{250}$ Under this mode of proceeding, if the police have probable cause to arrest, they could enter a man's apartment and in his absence conduct a search. If incriminating evidence is found, the pohce could wait for the suspect to return home, arrest him, and then conduct a search incident to the arrest. ${ }^{251}$ If the search proves unrewarding, they need not arrest and can wait for a more opportune time to make an arrest. ${ }^{252}$ Such a rule would discourage the procurement of search warrants and significantly encourage illicit searches prior to arrests in order to procure incriminating evidence. If the police think they have probable cause to beheve that a certain individual has committed a crime, then it should be a simple matter to draft a searcli warrant for the evidence sought to be obtained. The exclusion of evidence discovered before an arrest but seized incidental to the arrest would encourage this practice while securing the right to privacy.

When evidence is discovered by lawful means, the "independent source" exception is both a logical-for the police have not exploited an initial illegality-and a desirable doctrine. This exception, however, should not be permitted to emasculate the exclusionary rule. The independent source must be closely scrutinized to ascertain whether the alleged source has, in fact, been discovered by independent ineans or whether the independent source, in fact, owes its very discovery to illicit means. ${ }^{253}$

\section{The "Inevitable Discovery" Exception}

The inevitable discovery exception ${ }^{254}$ has been found to serve well the "raison d' etre of the exclusionary rule by denying to the government the

250 Cf. Harris v. United States, 331 U.S. 145, 197-98 (1947) (Jackson, J., dissenting).

251 Such action would "make the arrest an incident to an unwarranted search instead of a warrantless search an incident to an arrest," United States v. Rabinowitz, 339 U.S. 56, 80 (1950) (Frankfurter, J., dissenting). There is authority for the proposition that if the arrestee is not at home there can be no seizure of evidence even if it is in plain view. Trupiano v. United States, 334 U.S. 699, 707 (1948) (dicta). "To the extent that Trupiano . . . requires a search warrant solely upon the basis of the practicability of procuring it rather than upon the reasonableness of the search after a lawful arrest, that case is overruled." United States v. Rabinowitz, supra, at 66. The Rabinowitz decision thus concerns only searches incidental to arrest. See also Jones v. United States, 357 U.S. 493, 499-500 (1958).

252 "There is no constitutional right to be arrested." Hoffa v. United States, 385 U.S. 293, 310 (1966).

253 Compare United States v. Paroutian, 299 F.2d 486 (2d Cir. 1962), with Paroutian v. United States, 319 F.2d 661 (2d Cir. 1963), cert. denied, 387 U.S. 943 (1967).

254 See Killough v. United States, 336 F.2d 929 (D.C. Cir. 1964); McLindon v. United States, 329 F.2d (D.C. Cir. 1964); Wayne v. United States, 318 F.2d 205 (D.C. Cir,), cert. denied, 375 U.S. 860 (1963); Sullivan v. United States, 219 F.2d 760 (D.C. Cir. 1955) ; People v. Ditson, 57 Cal. 2d 415, 369 P.2d 714, 20 Cal. Rptr. 165 (1962). 
use of evidence 'come at by exploitation of . . . illegality' and at the same time minimizes the opportunity for the defendant to receive an undeserved and socially undesirable bonanza." 255 To establish the exception the prosecution must

satisfy the court, as a fact, that the proferred evidence would have been acquired through lawful sources of information even if the illegal act had never taken place. Since such act did in fact occur and, further, did in fact produce the evidence, this is not a simple task. ${ }^{250}$

It is axiomatic that the test cannot be what the police "could" or "should" have done. ${ }^{257}$ However, according to the cases and commentators which advocate or adopt the inevitable discovery exception, evidence which is discovered as a direct result of unlawful police conduct and has remained the fruit of the poisonous tree, may nevertheless be admissible if it would have eventually been discovered. ${ }^{258}$

The Supreme Court has not appled the inevitable discovery exception to primary evidence, refusing to allow the state to establisli defendant's identification in an illegal lineup where he had been denied counsel. ${ }^{250}$ The vitality of such a rule for second generation evidence must be measured against Wong Sun. The Wong Sun test is:

whether, granting establishment of the primary illegality, the evidence to which instant objection is made has been come at by exploitation of that illegality or instead by means sufficiently distinguishable to be purged of the primary taint. ${ }^{260}$

A literal reading of Wong Sun requires a rejection of the "inevitable discovery" exception, yet the "but for" rationale rejected by Wong Sun would permit sucl a rule. Arguably, since the test adopted was intended to be less restrictive of police activity, evidence admissible under the more restrictive "but for" test should also be admissible under the less restrictive Wong Sun test. There is force to the argument, but the ques-

255 Maguire, How To Unpoison the Fruit, The Fourth Amendment and the Exclusionary Rule, 55 J. Crac. I.C. \& P.S. 307, 317 (1964).

256 Id.

257 Britt v. Superior Court, 58 Cal. 2d 469, 473, 374 P.2d 817, 819, 24 Cal. Rptr. 849, 851 (1962). But see Coplon v. United States, 191 F.2d 749 (D.C. Cir. 1951), cert. denied, 342 U.S. 926 (1952); United States v. O'Brien, 174 F.2d 341 (7th Cir. 1949); Parts Mfg. Corp. v. Lynch, 129 F.2d 841 (D.C. Cir.) (dicta), cert. denied, 317 U.S. 674 (1942); Rouda v. United States, 10 F.2d 916 (2nd Cir. 1926) (dicta). One commentator suggests that a close reading of these cases reveals that the courts were in fact finding what would have been done. Maguire, supre note 255, at 314-16. See also In re Sans Laboratories, 115 F.2d 717 (3d Cir. 1940), cert. denied, 312 U.S. 688 (1941).

258 Maguire, supra note 255 , at $313-17$ and authorities discussed therein.

259 Gilbert v. California, 388 U.S. 263, 272 (1967).

200371 U.S. at 488 . 
tion appears to remain open. In any event, the desirability of the "inevitable discovery" exception must be examined.

A hypothetical will best illustrate the problem of applying such a standard to the discovery of witnesses. Asssume that the police, in a situation similar to that recorded by the book In Cold Blood, ${ }^{261}$ attempt to track down the murderers of the Clutter family and in consequence arrest Dick Hickock and Perry Smith. An interrogation takes place without the required warnings and two confessions are obtained. The confessions tell of Floyd Wells, to whom Hickock had disclosed his plans concerning the Clutters. The pohice then locate Wells and tell him that Smith and Hickock have confessed, indicating that he was implicated. Wells tells of his conversations with Hickock and agrees to testify at trial.

Assume further that the police had been investigating everyone who had worked for the Clutters, that they had questioned thirty out of forty names on the ist, and that Wells was the thirty-fifth name. Would the police have inevitably found this witness and, assuming they found him, would he have been willing to speak? Should the fact that they told him of his implication by the alleged murderers weigh heavily in determining the admissibility of his testimony? Of course, the pohice, without the illegal confession, could have told Wells that he had been implicated as a former employee of the Clutters, but the fact that they already knew the circumstances of his involvement would be crucial in Well's decision to speak. In such a situation, it is very difficult to believe that the witness would have given the same information, although it is easy to infer that the pohice would have found the witness.

With respect to tangible evidence, it is simple in hight of scientific methods of criminal investigation to establish that the evidence would inevitably have been discovered. If the "inevitable discovery" exception is designed to facilitate police work and allow the investigation to proceed from an unlawfully derived conclusion, then it is certainly justified. Whether it discourages illicit police conduct is another matter.

Dicta in People v. Stoner ${ }^{262}$ suggested that where well-established legal police practices would have produced identical evidence, the exception applies. Since the procedures already exist and are operating at the time of the individual officer's isolated mistake, what activity is there to deter by excluding relevant and trustworthy evidence?

But in the areas of frequent violations-search and seizure, wiretapping, and eavesdropping-it is extremely rare to find a normal, lawful police procedure which is regularly followed and inevitably would have disclosed the exact same information. Although statistics indicate that

261 T. CAPOTE, IN CoLd BLOOD (1965).

26265 Cal. 2d 595, 422 P.2d 585, 55 Cal. Rptr. 879 (1967). 
the number of unlawful searches is decreasing, ${ }^{208}$ we are still a long way from the day when official illegality will be the exception rather than the rule. If that goal is someday reached, then the normal police procedure criterion suggested in Stoner may be a valid test by whicli to permit the introduction of relevant and trustworthy evidence. For the present, the exclusionary rule, designed to discourage illegal police activity, is useless if the police may unlawfully invade a man's home, illegally seize evidence and then claim "we would have obtained it anyway." The ability of police scientists, laboratory technicians, and investigators to discover, analyze, and develop substantial leads from minute materials ${ }^{204}$ appears to make even the most implausible discovery virtually inevitable. The exclusionary rule is designed to encourage the development of such methods, not make their theoretical availability a reason for admitting illegally-seized evidence.

The logic of the "inevitable discovery" has a certain appeal, but it collides with the fundamental purpose of the exclusionary rule. If the Supreme Court adopts the inevitable discovery exception, it will mark a sharp break with Silverthorne, Nardone, and Wong Sun. The preservation of the exclusionary rule as a viable deterrent to illicit police activity requires the spotlight to focus "on actualities not probabilities."205

\section{Inadmissible Evidence To Impeach Credibility}

Whether illegally seized evidence of previous criminal activity may be used to impeach the defendant when he takes the stand to testify depends on the continued vitality of Walder v. United States. ${ }^{200}$ Careful consideration will suggest that it should be limited to its facts. In Walder the defendant, on trial for the illicit sale of narcotics, took the stand and on direct examination denied he had ever illegally purchased, sold, or possessed narcotics. On cross-examination he was questioned concerning a prior unlawful seizure of a heroine capsule from his home and denied that any narcotics had been taken from him at that time.

The prosecution proceeded to put on the stand an officer who participated in the unlawful searcli and the chemist who had analyzed the seized capsule. The jury was carefully instructed that this evidence was only to be considered for purposes of impeaching the defendant's credibility and not for proof of guilt of the crime for which he was then being charged.

283 See Nagel, Testing the Effects of Excluding Illegally Seized Evidence, 1965 Wrs. L. REv. 283.

264 See, e.g., H. Soderaman and J. O'Conner, Modern Crdminal. Investigation (1935);

CrRace and Its Detection (W. Shore ed. 1932).

205 United States v. Paroutain, 299 F.2d 486, 489 (2d Cir. 1962).

268347 U.S. 62 (1954). 
Mr. Justice Frankfurter, speaking for the Court, distinguished Walder from Agnello v. United States, ${ }^{267}$ wherein the defendant, who was indicted for conspiring to sell narcotics, was neither asked on direct examination nor mentioned anything about his possession of narcotics. The Government during its case had attempted and failed to introduce narcotics which had been unlawfully seized. On cross-examination the prosecution asked the accused if he had ever seen narcotics before. The question was answered in the negative and the Government then attempted to introduce evidence of the unlawfully seized narcotics. ${ }^{268}$

The Agnello Court rejected this attempt at impeachment, reasoning that the defendant had done "nothing to waive his constitutional protection to justify cross-examination in respect of the evidence claimed to have been obtained by the search." ${ }^{2268}$ Walder, on the other hand, had voluntarily opened the door on direct examination, and his conviction was affirmed. ${ }^{270}$.

Although Walder is distinguishable from Agnello on this ground, it is also important to recognize that the evidence in Agnello concerned the very narcotics which defendant was charged with conspiring to sell. Therefore it appears that Walder should be limited to situations where the defendant has placed his cliaracter or reputation generally in issue as distinct from denying essential elements of the crime cliarged. This appears to be a sound distinction, since there is little incentive for the police to illegally obtain evidence solely for impeachment purposes in a case that may or may not arise. If the illegally obtained drugs are the very narcotics for which the defendant is then on trial, his denial of their possession would be related to an essential element of the crime. Therefore, evidence of their procurement would not be admissible at trial as substantive proof or for purposes of impeachment. ${ }^{271}$

The Walder rationale lias been applied, however, to cases involving confessions to the crime charged with a distinction sought to be drawn between statements which are inculpatory per se and those which are not. ${ }^{272}$ But the prosecution, by using any statement, even if only to im-

267269 U.S. 20 (1925).

268 Record at 476, Agnello v. United States, 269 U.S. 20 (1925), cited in Walder v. United States, 347 U.S. 62,66 (1954).

269269 U.S. at 35.

270347 U.S. at 65.

271 See The Supreme Court, 1953 Term, 68 HARv. L. REv. 96, 114 (1954), where the authors properly suggest that if defendant had been unaware of the unlawful seizure then he could not have been impeached.

272 See, e.g., Tate v. United States, 283 F.2d 377 (D.C. Cir. 1960).

The Walder exception to the exclusionary rule has been limited, however, to impeachment: where defendant clearly perjures himself on direct examination, United States $v$. Curry, 358 F.2d 904 (2d Cir. 1967); Jackson v. United States, 311 F.2d 686 (5th Cir. 1963); 
peach the defendant's credibility, nevertheless uses a statement obtained in violation of the privilege against self-incrimination. Thus Miranda $v$. Arizon ${ }^{273}$ indicated that all statements of an accused-confessions or admissions-are inculpatory per se and, absent the required warnings, cannot be used. Althougl the prior inconsistent statement may not be used as substantive proof of guilt, the clestruction of the defendant's credibility, even thougl the actual contradiction is comparatively minor, may be as damaging as the most complete admission. ${ }^{274}$

When the accused takes the stand, the tool of cross-examination is the "principal and most efficacious test for the discovery of the truth."275 The interests of justice demand that the defendant as a witness be subject to the most searching examination by the prosecution. Dean Wigmore points out that the cross-examined witness "supplies lis own refutation."270

Commonwealth v. Reginelli, $208 \mathrm{~Pa}$. Super. 344, 222 A.2d 605 (1966); and where the perjury goes beyond the elements of the crime being tried, Inge v. United States, 356 F.2d 345 (D.C. Cir. 1966); Commonwealth v. Wright, 415 Pa. 55, 202 A.2d 79 (1964).

If a confession is excluded as substantive proof because it is unreliable, then this rationale requires its exclusion for purposes of impeachment. State v. Turnbow, 67 N.M. 241, 354 P.2d 533 (1960); Pearrow v. State, 146 Ark. 201, 225 S.W. 308 (1920); Shepard v. State, 88 Wis. 185, 59 N.W. 449 (1894). See also Gaertner v. State, 35 Wis. 2d 159, 150 N.W.2d 370 (1967), where the court holds that use of an "involuntary" confession to impeach defendant was error, but only a harmless one.

A separate and distinct question arises after the defense has used part of an inadmissible statement whether the government can use the entire statement in rebuttal. See Hicks v. Umited States, 382 F.2d 158 (D.C. Cir. 1967).

273384 U.S. 436 (1966). No distinction can be drawn between statements which are direct confessions and statements which amount to "'admissions' of part or all of an offense." Id. at 476. Accord, White v. United States, 349 F.2d 965 (D.C. Cir. 1965); Jolnson v. United States, 344 F.2d 163 (D.C. Cir. 1964).

Chief Judge Bazelon in Johnson indicates that Walder was not concerned with a confession which may work greater prejudice to the defendant. Whether the prejudice exists in giving very great impeaching weight to the prior inconsistent statement or from the possibility that the jury nuay not follow instructions is not clear from the opinion. Additionally the opinion states that the illicit evidence in Johnson relates directly to the indictment and the "officer's testimony directly challenged the innocence, not nierely the credibility of the defendants." Cf. Compton v. United States, 334 F.2d 212 (4th Cir. 1964) (Walder held applicable to a proceeding for tax refund) Contra, People v. Kulis, 18 N.Y.2d 318, 221 N.E.2d 541, 274 N.Y.S.2d 873 (1966) (per curianı); State v. McClung, 66 Wash. 2d 654, 404 P.2d 460 (1965) (en banc); see Fernandez v. Delgado, 257 F. Supp. 673 (D.P.R. 1966). See also State v. Brewton, 422 P.2d 581 (Ore. 1967).

274 Commonwealth v. Padgett, 237 A.2d 209 (Pa. 1968) (the court held, however, that the use of an inadmissible confession to impeach the credibility of defendant to be harmless error). Compare Miranda v. Arizona, 384 U.S. 436, 464 n.33 (1966); Wheeler v. Unitcd States, 382 F.2d 998, 1001 (10th Cir. 1967); People v. Luna, 37 Ill. 2d 299, 226 N.E.2d 586 (1967). See also White v. United States, 349 F.2d 965 (D.C. Cir. 1965); Johnson v. United States, 344 F.2d 163 (D.C. Cir. 1964). Contra, People v. Kulis, 18 N.Y.2d 318, 221 N.E.2d 541, 274 N.Y.S.2d 873 (1966) (per curiam).

$275 \mathrm{~W}$. RICHARDSON, supra note 167,8500 .

2705 J. WIGMIORE, EVIDENCE \& 1368 (1940). 
In many situations the defendant's only hope for acquittal lies in his credibility as a witness in his own behalf, and it is his constitutional right to take the stand and deny the charges against him. The threat of impeachment by illegally seized evidence-a confession or tangible evidence -should not be permitted to discourage the exercise of this right. ${ }^{277}$ Additionally, as recognized by the Oregon supreme court, the admissibility of such statements only gives additional incentive for interrogation without the Miranda warnings. ${ }^{278}$

From the foregoing, it appears that neither an illegally obtained confession or admission nor other illegally seized evidence of the crine charged should be admissible for impeachment purposes at trial, at least where such evidence, if admissible, would be relevant as substantial evidence.

What then, if anything, remains of Walder? A careful analysis of that decision reveals that the defendant, by denying that he had ever used, possessed or sold narcotics, was effectively placing his character in issue. ${ }^{279}$ The evidentiary problems surrounding character and impeachment tecliniques thus bear upon the present status of Walder. Once a defendant has put character in issue, ${ }^{280}$ the prosecution may offer proof of the defendant's reputation in the community. ${ }^{281}$ If the defendant has had other witnesses testify as to his character, then the prosecution may ask each witness if he has heard that defendant had been arrested for a certain crime relevant to the character trait which the witness' testimony is intended to establish. ${ }^{282}$ Although Walder was not a character witness, his statement opened the door and put his character in issue. When the defendant takes the stand, he may be impeached in the same way as the

277 Cf. Griffin v. California, 380 U.S. 609 (1965). "The privilege granted to an accused person of testifying in his own behalf would be a poor and useless one indeed if he could exercise it only on condition that every incompetent confession ... should hecome evidence against him." Harrold v. Oklahoma, 169 F. 47, 50 (8th Cir. 1909).

278 See State v. Brewton, 422 P.2d 581 (Ore.), cert. denied, 387 U.S. 943 (1967). See also Developments in the Law-Confessions, 79 HARv. L. REv. 935, 1030 (1966).

270 But see People v. Hinksman, 192 N.Y. 421, 85 N.E. 676 (1908) where the defendant on direct examination was asked if he had ever been in any trouble. He replied that he once was convicted of grand larceny but that was the only trouble he had ever been in. The accused then gratuitously added, "I have been a good boy ever since." Id. at 429,85 N.E. at 678 . The court held that this statement did not put his character in issue. This holding is criticized in $1 \mathrm{~J}$. WIGMoRe, sulpra note $276, \S 58 \mathrm{n} .2$.

280 The accused alone has the power to put his character in issue. C. MCCormick, EvDENCE § 158 (1954). This requirement is to alleviate the danger of "undue prejudice," that the jury may give excessive weight to evidence of the defendant's bad character. W. RICHARDSON, supra note $167, \S 154$.

281 Michelson v. Umited States, 335 U.S. 469 (1948).

282 Id. W. RICEARDSON, supra note 167, § 157. Contra, C. MCCoRMarC, supra note 280 , \$ 158. This author suggests that you may ask if the witness knows of repeated arrests. 
ordinary witness. ${ }^{283}$ of the traditional impeachment methods available, only the question of whether the defendant had ever committed an immoral act appears to be relevant to the question at hand. ${ }^{284}$ Thus, the prosecution could call members of the community, ask them about Walder's reputation and inquire into whether they had heard that he had ever been arrested on a narcotics charge ${ }^{285}$ or whether the community had talked about the defendant's narcotics activities. ${ }^{288}$

This "disparaging rumor" method of impeaching a character witness -or, in Walder, the defendant himself-may be a covert attempt to put particular facts before the jury and must be strictly controlled. It has been suggested that the prosecuting attorney be required to assure the judge that there exist "reasonable grounds to believe ... that the crimes or misconduct, which are imputed by the rumors, or which are the subject of the arrests or charges, were actually committed by the accused . . ."287 before questioning the character witness about the "disparaging rumor."

It is here that the inadmissible evidence or confession causes problems. There is no doubt that Walder was arrested, but since illegally obtained evidence may not be used as probable cause to secure a search warrant, is it proper to allow such evidence-in his case a heroin capsule -to be the basis of reputation impeachment? The defendant must in all cases "open the door" before the prosecution can attack his character. Does this, in effect, make any defendant's affirmative action placing his character in issue identical to the perjury committed in Walder?

Mr. Justice Frankfurter made it clear that the accused may take the stand and deny all of the elements of the crime without contradiction by the use of illegally obtained evidence. Evidence of good character may, with other evidence, create a reasonable doubt of guilt. In some cases such evidence, standing alone, may create such doubt where none existed before. Therefore, the right to establish one's good character appears

283 W. RICHARDSON, supra note $167, \S 158$.

284 Any act of misconduct having "some fair tendency to show moral turpitude" is admissible to impeach a witness. W. RICHARDSON, supra note 167, \& 577. See also C. McCoracick, supra note 280, \& 43, and cases collected therein. The Uniform Rules of Evidence permit impeachment by use of prins conviction or acts of misconduct only to the extent that such are relevant in regard to the veracity of the witness. Uniform Rules of Evidence, rules 21, 23 (4) (1953). See also Model Code of Evidence, rules 106 (3), 233 (1942).

285 The "did you hear" questions should be confined to the character trait in issue. 3 J. WIGMORE, supra note 276 , § 988. W. RICHARDSON, supra note 167, § 155. If, however, the character witness testifies concerning defendant's reputation for traits broader than the crime charged, then the prosecution may on cross-examination ask, "did you hear" questions to the extent of the scope of the direct examination. Michelson v. United States, 335 U.S. 469 (1948).

286 Michelson v. United States, 335 U.S. 469 (1948).

287 C. MCCormacK, supra note $280, \S 158$. See also 3 WIGMore, supra note $276, \S 982$. 
analogous to the right to deny the elements of the crime, and the Walder exception should not come into play.

However, the manner in which Walder placed his character in issueby his own direct perjury-should permit the "disparaging rumor" questioning of other character witnesses, or the defendant himself, regardless of any reasonable grounds for belief on the part of the prosecutor. If the requisite belief exists without the use of illicit evidence, then the problem does not, of course, arise.

If there is no "reasonable grounds" requirement for the prosecutor, then a "disparaging rumor" question may be asked of a witness with or without reasonable grounds for belief that the accused was arrested, possessed drugs, or committed another crime. If this be so, then it is irrelevant that the sole basis for the question comes from the knowledge illegally obtained since the question may be asked without any evidence, lawfully or unlawfully obtained, at its foundation.

To illustrate how the "reasonable grounds" rule works in an unlawfully obtained confession context, let us assume that $A$ confesses to the rape of $B$, but because of the failure of the police to warn him of his rights, the charges against him are dropped. One year later $A$ is again arrested for rape (this time of $X$ ) and, at his trial, takes the stand to testify on his behalf. His direct testimony only covers the fact of the rape for which he is on trial. On cross-examination, the prosecutor asks him if he ever raped anybody. This question is designed to establish his immoral character and show him to be an untrustworthy witness. Such an impeachment technique is considered a collateral matter, and the prosecutor will be prevented from introducing any extrinsic evidence- the prior confession-to establish the specific immoral act. ${ }^{288}$ However, the prosecutor may continue on cross-examination to pursue the matter in an attempt to procure an admission-the bounds of such questioning being within the sound discretion of the trial judge.

If the illegal confession was the only link between the defendant and the first rape, then the prosecutor, if required to establish a reasonable basis for the questioning concerming the prior act, would necessarily be using the confession for such purposes. Since the possibility of prejudice to the accused is extremely great, a judge would be wise to exclude immediately such a question with only an illicit confession at its foundation. ${ }^{280}$

In each situation, the controlling question must be: For what purpose is the evidence being offered, and what are the requirements of the par-

288 C. MCCormICK, supra note $280, \S 43 ; 3 \mathrm{~J}$. Wrgmore, supra note $276, \S 979$.

280 Several state courts prohibit questions concerning prior misconduct. See C. McCormick, supra note $280, \S 43$. 
ticular rule of evidence? The hypothetical demonstrates that illegally seized evidence, which is not relevant as substantive proof of guilt, will seldom pose a problem of admissibility in impeachment situations.

However, if in direct testimony, $A$, in response to his counsel's question, affirmatively denies he has ever committed rape, the door to a character attack is opened as in Walder. In such a situation, the defendant himself has opened the door by committing perjury. There is very hittle chance that admissibility under such limited circumstances-and in situations where the illicit evidence would not be relevant as substantive proof of guilt-will be any real incentive for the police to obtain such evidence. ${ }^{200}$ The sanctity of the courtroom and the integrity of the judicial system require that perjury be prevented, and this policy outweighs exclusionary considerations in this one very narrow situation.

VI

EVIDENCE OBTATNED BY EXPLOITATION OF THE ILLEGALITY VS. MEANS

SUFFICIENTIY DISTINGUISHABLE TO BE PURGED OF THE PRIMARY TAINT

\section{A. Illegal Lineups and Subsequent Identifications}

Identifications made during a period of unlawful custody in the absence of counsel and the identifying witness' subsequent testimony at trial create some very perplexing problems. Just last term the Supreme Court focused on police identification procedure in United States $v$. Wade. ${ }^{201}$ Citing a recent article, the Court indicated that "[i]t is a matter of common experience that, once a witness has picked out the accused at the line-up, he is not likely to go back on his word later on, so that in practice the issue of identity may (in the absence of other relevant evidence) for all practical purposes be determined there and then, before the trial." "'282 Thus, reasoned the Court, a postindictment lineup was a critical stage of the criminal proceeding necessitating the protection provided by the assistance of counsel. ${ }^{203}$

The absence of counsel at a postindictment lineup will accordingly operate to exclude any testimony relating to the lineup or identifications made at that proceeding. ${ }^{294}$ The more interesting and complex problem is

280 See Note, Fruit of the Poisonous Tree-A Plea for Relevant Criteria, 115 U. PA.

L. REv. 1136 (1967).

201388 U.S. 218 (1967). See also Gilbert v. California, 388 U.S. 263 (1967); Stovall v.

Denno, 388 U.S. 293 (1967).

202388 U.S. at 229.

293 Id. at 236-37.

284 Gilbert v. California, 386 U.S. 263, 272-74 (1967). Testimony at trial concerning a lineup during a period of unlawful detention has been held inadmissible. Jacobson v. United States, 356 F.2d 685, 688 (8th Cir. 1966) (dicta); Edwards v. United States, 330 F.2d 849, 851 (D.C. Cir. 1964) (approval of trial court's ruling). The Supreme Court's ruling in Gilbert v. California, supra, presents some difficult problems. If defendant is arrested after in- 
the effect of the initial identification on the subsequent trial identification. The Court, using the "fruit of the poinsonous tree" rationale, refused to adopt a rule of per se inadmissability with respect to the subsequent trial identification, and instead stated the test as:

Whether, granting establishment of the primary illegality, the evidence to which instant objection is made has been come at by exploitation of that illegality or instead by means sufficiently distinguishable to be purged of the primary taint. ${ }^{295}$

The crucial question for this Article is whether the admissibility of the courtroom identification would encourage the police to use illegal and unfair lineups to procure an identification and guarantee a witness' testimony at trial.

The application of attenuation in this context appears, however, to be warranted for, in effect, the Court is asking whether the illegal lineup has resulted in the courtroom identification. The application of the attenuation doctrine requires a careful examination of the facts of each case in order to determine whether a trial identification is tainted by a previous identification at a defective lineup. ${ }^{298}$ In Wade, the Court indicated some of the relevant factors:

$[T]$ he prior opportunity to observe the alleged criminal act, the existence of any discrepancy between any pre-lineup description, any identification prior to lineup of another person, the identification by picture of the defendant prior to lineup, failure to identify the defendant on a prior occasion, and the lapse of time between the alleged act and the lineup identification.

It is also relevant to consider those facts which, despite the absence of counsel, are disclosed concerning the conduct of the lineup.297

An examination of the facts of People v. Stoner ${ }^{208}$ will illustrate the type of analysis needed to establish attenuation. In Stoner the defendant appeared in a "showup"289 wearing clothes which had been illegally

dictment there will be in almost every case probable cause to arrest and counsel must be present at a lineup. If a lineup is a critical stage of the criminal process is it any more crucial if held before or after indictment? If there is no distinction between post and prejudicial stage lineups and assuming counsel's presence, what is to be done with the suspect who is illegally arrested and subsequently identified in a totally rehable lineup? Is the right to be free from unlawful seizure of the person to be subverted to society's need for the identification of criminals? Such a rule appears to issue an open invitation for dragnet arrests-or arrests on mere suspicion-in order to procure possible suspects for lineups.

295388 U.S. at 241.

208 Id. at 242 .

297 Id. at 241.

29865 Cal. 2d 595, 422 P.2d 585, 55 Cal. Rptr. 897 (1967).

209 It is unclear whether the defendant "stood" with other individuals. The word "showup" in California appears to refer to the lineup of several individuals. See People v. Branch, 127 Cal. App. 2d 438, 439, 274 P.2d 31, 32 (1954). 
seized from his hotel room. The opinion is somewhat vague, but it appears that Stoner was the only person in the "showup" who was dressed in clothing similar to that worn by one of the holdup men. A witness, Greeley, then identified the defendant. At the trial, the "showup" identification was excluded, but the prosecution sought to have Greeley identify Stoner as one of the robbers. Defense counsel objected, claiming that the identification at trial was only possible because of the previous "showup" identification..$^{300}$

In a hearing before the trial judge, out of the presence of the jury, Greeley stated that on the evening of the robbery one of the holdup men stood beside him for approximately five minutes and had spoken several times. Greeley compared the defendant's appearance, actions, and speech durmg his various courtroom appearance ${ }^{301}$ and concluded that the defendant was one of the robbers. ${ }^{302}$ Greeley was permitted to testify, the trial judge finding that the courtroom identification would be sufficiently distinct fron the showup identification. ${ }^{303}$

The pivotal questions in Stoner would seem to be whether the courtroom identification was affected by the "showup" and, if so, to what degree. The opinion relies on psychological authorities who conclude that it may be inpossible for a person to forget a significant perception and prevent stored remembrances from subconsciously affecting his later perceptions and decisions. ${ }^{304}$ The "showup" must, therefore, have had some affect.

The extent to which the "showup" affected the subsequent identification then becomes the focal point of concern. ${ }^{305}$ The validity of the witness' first description and the basis of the identification in the "showup"

300 It is implicit from Stoner that only the defendant was required to put on the illegally seized clothing and glasses. The court indicates that a tentative identification of the defendant was made by the store clerks, based on a picture of defendant. $65 \mathrm{Cal} .2 \mathrm{~d}$ at 597, 422 P.2d at 586, $55 \mathrm{Cal}$. Rptr. at 898 . The lower court opinion indicates that Greeley did tentatively identify Stoner from the picture. People v. Stoner, 50 Cal. Rptr. 712, 713 (1966).

801 Greeley also identified Stoner at the preliminary examination and the first trial. 50 Cal. Rptr. at 714.

302 The testimonial value of the courtroom identification has been seriously questioned.

4 J. WigMrore, supra note 276, § 1130; J. Frant aNd B. Frant, Nor GuIltx 148-50 (1957). See also P. WaII, Exe-Witaness Identrfication In Crmminal Cases 188 (1965).

${ }^{303}$ The court of appeal reversed the trial judge, refusing to speculate on the degree of taint renraining from the lineup identification. 50 Cal. Rptr. at 714.

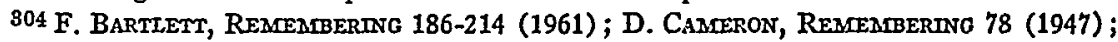
5 S. FreUd, Collected Papers 175-80 (Starchey ed., 1950), cited in Stoner, 65 Cal. 2d at 602,422 P.2d at 589, 55 Cal. Rptr. at 901.

305 At this point the author wishes to acknowledge the invaluable assistance of Melville Elizabeth Ivy, a first-year medical student at the University of Michigan, in preparing the following discussion. In addition the author is indebted to Robert B. Brooks of Clark University for his aid in this presentation. 
will determine the actual taint of the courtroom identification. Immediately after the robbery Greeley told police that one of the holdup men wore a gray sweater or jacket, gray pants, a gray shirt, horn-rimmed glasses, and carried a gray forty-five. He also stated that during the holdup the thief stood in front of him for about five minutes and spoke several times. The nature of this descriptive data is not what psycliologists would call recall or remembrance-the ability of a person, without the aid of any visible or overt stimuli to remind him of a past incident or object, to remember a fairly well-organized, detailed, and structured description of the thing being remembered.

The witness' superficial description, not mentioning height, age, or hair color, as well as the situation do not indicate valid recall in this instance. Few would question the novelty and high emotionality surrounding a robbery. Psychologists are generally very sceptical about the accuracy of recall or remembrance under conditions of marked excitement, ${ }^{306}$ for there is little tendency to make organized and detailed observations under these conditions.

The one factor to which the witness does refer in some detail is the suspect's voice and demeanor. But the detailed description of this factor, whicl would warrant its consideration as an example of recall, appeared only after the "showup," leavnig open the question whether it existed immediately following the robbery. The fact that Greeley, when first questioned by the police, mentioned that the thief spoke several tinies during the robbery miglit indicate a dominant auditory sense modality whicl would cast further doubt on the accuracy of Greeley's other sensory modalities. ${ }^{307}$ During suclı a short exposure, our senses tend to substitute one for another - "we hear a person's voice and imagine we see his face." ${ }^{\prime 308}$ Therefore, it appears that the degree of recall here is mininial.

We seem rather to be dealing with the phenomenon of recognition which involves none of the structure detail of recall. Rather the subject, on the basis of an actual stimulus presented or persisting after the fact, experiences a feeling of familiarity or a revival of the past event that would probably go unremembered without an exciting cue or arousal. In recognition the immediate stimulus is some sensory pattern that matches past psychological material from the initial event. ${ }^{309}$ To the extent that the identification of the suspect was initially based on recognition rather than recall, the influence of the "showup" on the courtroon identification would be immeasurably greater.

308 H. BURTt, Legai Psychology 76 (1931).

307 Id. at 49.

308. It may very well be that if Greeley is an auditory perceiver then his visual acuity may be correspondingly weaker. F. BARTLETT, supra note 304, at 192.

309 Id. at 195 . 
It is very likely that anyone dressed exactly like the suspect and viewed in a lineup would promote revival of a formerly perceived figure and lead to an identification of the present stimulus with the former. With this reinforcement, the observer is free to expand his view by solidifying certain perceptions and go on to the consideration of others which will tend to complete his image or memory of the event. The observer might then attend to hair color, stature, demeanor, voice, or other factors which were neglected and less salient in the original identification which depended on purely sensory processes (as evidenced here by Greeley's initial testimony.) These later perceptions serve to organize the memory to add the details needed to complete the description appearing in subsequent identifications such as that in the courtroom. This identification is then recall, but only because of the infiuence of the "showup" which provided the witness with sensory reinforcement and the opportunity to go beyond mere recognition to actual perception and recall.

Therefore the degree to which the courtroom identification was influenced or "tainted" by the "showup" depends on the extent to which recall existed before the "showup." Only this type of memory could be judged sufficiently purged of the "showup." As recognition depends heavily on subsequent cues to reinforce and provide a basis for the detail and organization necessary for recall, it must be judged tainted. There is no evidence in Stoner, either in the immediate testimony of the witness or in the psychological literature on the subject, that recall was established. The subsequent disclosure of the witness that his courtroom identification depended mostly on demeanor and voice recognition of the suspect occurred only after the showup. There is no evidence of it before. Thus, we must conclude that there is just as mucl likelihood that this reliable form of recall memory developed as a result of the reinforcement of the "showup" situation as that it was present all along. The unequivocal judgment that the identification was sufficiently independent of the "showup" is unwarranted. The nature of perception and memory makes it questionable whether recall took over for recognition before or after the "slowup."

In Stoner the court, while reversing the conviction, clearly stated that "[a]lthough it may be impossible for a person to forget a significant perception and to prevent stored remembrances from subconsciously affecting his later perceptions and decisions [citations omitted], it does not follow that the testimony of a person in Greeley's position should be excluded." ${ }^{\prime 310}$ The court was convinced that the subsequent observation of speech and demeanor, along with the witness' statements of his reliance

31065 Cal. 2d at 602, 422 P.2d at 589, 55 Cal. Rptr. at 901. 
on these factors, was sufficient to "purge the taint" of the primary illegality.

In People v. Caruso ${ }^{311}$ the California court appeared to reconsider its decision in Stoner. Caruso, decided after Wade, held that a pre-Wade lineup without counsel was fundamentally unfair and inherently suggestive. The court set out guidelines for the retrial of the defendant, requiring that the prosecution establisl by clear and convincing evidence that the identifications at the trial "were based upon observations of the accused at the scene of the robbery." 312 According to the court, the illegal lineup served to "firm-up" the niemories of the witnesses and enable them to identify the defendant at trial. Thus, at the retrial the witnesses "must totally eliminate from recollection all observations at the lineup and convince 'every reasonable mind' that they distinctly recall defendant from their fleeting impressions during the robbery." edges, subsequent observations are affected by the initial identification, and reason and science, as well as the Supreme Court, ${ }^{314}$ require that only observations of the suspect made prior to the illegal identification be considered in determining the validity of a subsequent identification.

\section{Mixed Methods}

\section{B. Attenuation}

Although illegally obtained evidence may be utilized in the ultiniate procurement of other evidence, the secondary evidence may nevertheless be admissible if it has been derived from "means sufficiently distinguishable to be purged of the primary taint." Problems arise when legal and illegal methods are combined to procure evidence. In some situations affidavits which serve as the basis for search warrants contain facts which were obtained through unlawful means. If, absent these facts, probable cause does not exist, the search will be found illegal..15 If, absent the tainted facts, sufficient information remains to establish probable cause, then the search will be valid. ${ }^{316}$ If a court finds the two methods so

31168 A. C. 181, 436 P.2d 336, 65 Cal. Rptr. 336 (1968).

312 Id. at 188, $436 \mathrm{P} .2 \mathrm{~d}$ at 341, $65 \mathrm{Cal}$. Rptr. at 341. It is interesting to note that Caruso failed to cite Stoner.

313 Id.

314 United States v. Wade, 388 U.S. 218, 241 (1967).

315 Hair v. United States, 289 F.2d 894, 895 (D.C. Cir. 1961) ; State v. Hagen, 258 Iowa 196, 137 N.W.2d 895 (1965); State v. Dufour, 206 A.2d 82, 87 (R.I. 1965). It is clear that an officer cannot rely upon illegally obtained evidence to support an arrest or search without a warrant. Vanella v. United States, 371 F.2d 50, 54 (9th Cir. 1966).

$\mathbf{8 1 0}$ On appeal the appellate court may find the inclusion of the tainted information in the affidavit to be harmless error. Cf. Chapman v. California, 386 U.S. 18 (1967). The reviewing court may determine for itself that absent the unlawful information the warrant would have issued. Or the court may remand the issue to a lower court for such a determination. Cf. Jackson v. Denno, 378 U.S. 368 (1964). 
inextricably intertwined as to prevent a definite determination of whether the illegal component is sufficiently attenuated to permit the introduction of the evidence, then the derivative eviclence should, arguably, be excluded.

\section{2. "Purging the Taint"}

There exist, however, situations where the illegality has in some manner resulted in the procurement of evidence, but where the improper activity so clearly plays a de minimus role that the true attenuation occurs -for example, Costello v. United States. ${ }^{317}$ Although Costello's appearance before the grand jury was caused by the illegal wiretap, his admissions concerning prior and unrelated conduct were not prompted by the initial illegality.

A more difficult case is Gregory v. United States. ${ }^{818}$ In that case pohice illegally arrested appellant and his brother at the latter's apartment. Two policemen remained behind in lope of apprehending others believed to be involved in the crime. The following morning when one of the officers went to use the telephone to check with headquarters, he saw a newspaper clipping on the telephone. The article dealt with an entirely different crime (housebreaking) whicl became the subject of Gregory. From the newspaper article the police suspected that the defendant was also involved in this crime. An investigation disclosed that he had given both his wife and mother furs which were later found to be among the items taken in the housebreaking. A subsequent article appeared in the newspaper, and one Cook contacted the police about certain furs which Gregory had sold him.

Defendant sought to exclude the furs obtained from his mother and wife and to prevent Cook from testifying. The trial court admitted both the furs and the testimony. On appeal the prosecution suggested that the defendant was "grasping at straws" but nevertheless recognized the implication of defendant's argument. ${ }^{310}$

Although the circuit court of appeals found the question a close one, it affirmed the conviction per curiam, holding that "the connection between the evidence and the previous misconduct of the police was 'so attenuated as to dissipate the taint [citation omitted]." "320 The court was apparently impressed by the fact that the police were not making

317365 U.S. 265 (1961).

318231 F.2d 258 (D.C. Cir.), cert. denied, 352 U.S. 850 (1956). The decision was per curiam and the facts are taken from the Government's brief.

310 See Brief for Apellee at 9.

$\mathbf{8 2 0}$ Gregory v. Umited States, 231 F.2d at 259. See also People v. Bright, 59 Cal. Rptr. 372 (1967); State v. Jones, 250 La. 1007, 201 So. 2d 105 (1967). Cf. Williams v. United States, 382 F.2d 48 (5th Cir. 1967). 
a search, that the day before there had been an exhaustive search of the apartment, and that the only purpose for police presence at the apartment was to apprehend another party.

\section{Electronic Surveillance}

Assuming arguendo that the decision in Gregory may well be a proper application of the attentuation doctrine, can the same be said for situations involving wiretapping or eavesdropping? Consider the following hypothetical:

The Bureau of Narcotics, believing $X$ to be in the hierarchy of an international narcotics syndicate, wiretaps his plone and places an electronic listening device in his office. Among others the following conversations are overleard:

1. $X$ is called by $L$ who informs him that a supply of narcotics is to be delivered at a specific warelouse at $10 \mathrm{p.m}$. the next evening.

2. $X$ is contacted by $M$ who wants him to "fix a judge."

3. $N$, while in X's office, speaks of counterfeit money orders and their future distribution.

4. $O, X$ 's brother, comes to his office telling of his troubles with IRS and asks $X$ to suggest a lawyer to assist him.

As a result of this information, the Narcotics Bureau:

Places an agent at the warehouse the next evening who observes $X$ accepting the narcotics.

2. Notifies the Justice Department which contacts the judge who agrees to tape-record the subsequent conversation with $X$.

3. Notices the FBI who put a twenty-four hour surveillance on $N$, who leads them to $P$, who in turn is arrested when he attempts to pass the money orders. $P$ imphicates $N$ who confesses, implicating $X$. $X$ is arrested and after validly waiving his rights, confesses.

4. Contacts the IRS and gives them the information overheard in the conversation between $O$ and $X$.

The Government in Gregory urged that merely because an investigation is based upon an imitial illegality, this fact should not preclude forever the prosecution of a criminal for the particular crime disclosed. In each of the hypotheticals we deal with information derived from unlawful electronic surveillance-which had as its purpose gathering information about $X$ 's narcotics activities. The informer was placed in position ${ }^{321}$ only by virtue of the illegal surveillance, and his testimony and knowledge appear to be the direct result of the wiretapping.

The second and third hypotheticals involve crimes other than the one under investigation. Nevertheless, grounds to exclude evidence derive from the primary illegality. In the second hypothetical the Government has been informed of the possibitity of a future crime, and only

321 Cf. McDonald v. United States, 335 U.S. 451, $458-59$ (1948) (Jackson, J., concurring). 
because its agents were in position as a result of the primary illegality were they able to obtain evidence of the subsequent bribe. When the Government wiretaps, it is foreseeable, if not intended, that information concerning activity other than that under investigation will be overheard.

In the third hypothetical it can be argued that $X$ 's voluntary admission is distinct from the illegal wiretap. Yet, were it not for that tap, the FBI would never have known of $N$, and therefore could not have been put on the trail of $P$. Thus the process which led to $X$ 's admission has as an essential element the initial illegality. The acceptance of attenuation to purge the initial illegality would present a very great incentive for the police to wiretap, obtain information about prospective crimes, and then position themselves to arrest and "lawfully" seize evidence. The ends sought to be achieved-the prevention and prosecution of crimeare indeed laudatory, but the means by which those ends are sought to be attained require the exclusion of any evidence which significantly encourages the use of such methods.

The Government may persuasively argue, of course, that it would have had the "special agent" at the warehouse in any event, that the judge would have contacted the authorities, and that $N$ and $P$ eventually would have been caught attempting to pass the money orders. ${ }^{322}$ Perhaps this is true, but to quote a Detroit police inspector: "You can get the information you need if you just go out and develop it. But some of the boys would rather sit in an easy chair with the earphones on."328 The inevitable discovery doctrine, as previously discussed, ${ }^{324}$ is inconsistent with the fundamental purposes of the exclusionary rule and especially pernicious in the area of unlawful electronic surveillance. When, if ever, may the government utilize information gained by unlawful electronic surveillance? In dealing with information about a specific crime, past or future, the answer should be never-only absolute prohibition will suffciently discourage such methods. ${ }^{325}$

Althougl in most situations involving knowledge of a specific crime there will be extreme difficulty in establishing attenuation, the inde-

322 In Avey v. State, 228 A.2d 614 (Md. 1967), the court assumed that it was illegal for a detective to listen in on a telephone conversation with the permission of only one of the parties. The defendant argued that as a result of that conversation his subsequent arrest was illegal and evidence seized incident to that arrest was inadmissible. The court dismissed the argument by stating that the only result of the eavesdropping was the defendant "was arrested sooner than he may have been otherwise." 228 A.2d at 618.

323 W. FATRCHID \& C. CIIFT, ThE WIRETAPPERS 76 (1962).

324 See text accompanying notes 254-65 supra.

325 Cf. Bubis v. United States, 384 F.2d 643, 648 (9th Cir. 1967): "[A]ppellant will go unwhipped of justice, nevertheless ... that fact is less important than that the telephone company should not resort to unreasonable and unnecessary [wiretap] practices." 
pendent source exception is still available. ${ }^{326}$ In cases of unlawful electronic surveillance special care must be taken to establish an independent source. Such a source should exist before the illegal wiretapping or eavesdropping disclosed the second source. The government should establish that its agents had utilized that source before gaining knowledge by the unlawful method. This will insure that the independent source is not affected by the power of suggestion from the illegally obtained information.

Assume the police learn, by an illegal wiretap, the identity of an individual who is, or might be, a seller of narcotics. A special agent is sent out and purchases narcotics from the suspect. This course of events may be so infrequent and unanticipated that toleration of such police practice may not significantly dilute the force of the exclusionary rule. On the other hand, since electromic surveillance is inherently indiscriminate, it might be argued that anything discovered by use of such surveillance should be deenied sufficiently foreseeable to warrant its exclusion. That is to say, if we permit the seller to be prosecuted for this sale, we present law enforcement with too substantial an incentive to wiretap and eavesdrop.

The identity of the prospective seller is now known. What if police observe a sale independent of any encouragement on their part? What if, for example, in the course of investigating an individual whose identity has been disclosed by illegal electronic surveillance, the police discover his complicity in a previously unsolved crime? Or what if the police learn of the identity of an individual whom they connect with a subsequent crime?

In each hypothetical the individual's identity has been discovered by unlawful means, but no knowledge of a specific crime has been obtained. The only result is that a legal investigation of the suspect's activity-past, present, and future-has been commenced. This is a difficult situation and one which courts will resolve by holding the criminal act to be "sufficiently purged of the primary taint." As this Article lias attempted to illustrate, we are concerned with the deterrence of illegal police conduct. Under a strict deterrence-causation rationale, it could be persuasively argued that even here, such a suspect should not be prosecuted. Even if such use is proscribed, we do not grant immunity from prosecution. The independent source exception permits an investigation of an individual if his complicity is discovered by use of a lawful source.

The use of illegal surveillance constitutes a maximum invasion of privacy and consequently merits maximum deterrence. A rule prohibiting

826 See text accompanying notes 240-52 supra. 
any and all use would therefore seem in order. Thus when dealing with electronic surveillance of the defendant's activity the prosecution should be required to establish that such activity has not been used in this prosecution. This is a very extreme position which admittedly no court has yet adopted and perhaps never will. But continued adherence to illicit electromic surveillance may necessitate such a rule in order to discourage the use of sucl methods.

This approach-disallowing any attenuation-appears to be a simple and effective way to deal with the use of unlawful methods of electronic surveillance. The practical difficulties involved, however, are obvious. Since eavesdropping and wiretapping are clandestine operations, they may be very difficult to ascertain. Of course, if such electronic surveillance is legal-by court authorization-then the prosecutor should be required to inform the defendant before trial of the surveillance. ${ }^{327}$ If, however, illegal electronic surveillance has been unclertaken, the practicalities of discovering such activity present formidable problems. The defendant should be permitted to demand from the prosecuting attorney an unequivocal statement concerning the existence or nonexistence of electronic surveillance. ${ }^{328}$ Full disclosure of the prosecutor's case file may be another means of discovering whether or not defendant has been under surveillance. ${ }^{329}$ Once illegal electronic surveillance has been shown, then the defendant slould have the right to examine all transcripts or actual recordings in order to prepare lis derivative evidence presentation. ${ }^{330}$

The critical question when dealing with attenuation should be whether the admissibility of the challenged evidence will create an incentive for illicit police activity in the future. The attenuation doctrine can play an important role in the application of a derivative evidence rule. Experienced trial judges must carefully scrutinize sophisticated arguments which attempt to make the illegal link in the chain appear weak when, in fact, the entire chain depends on and encourages illicit police activity.

327 Blakey, Aspects of the Evidence Gathering Process In Organized Crime Cases: A Preliminary Analysis, in TASK RePORT: ORGanized Crane 80, 104 (President's Commission on Law Enforcement and Administration of Justice 1967).

328 See Sullivan, Wiretapping and Eavesdropping: A Review of the Current Law, 18 Hastings L.J. 59, 70 (1966).

329 Cf. Brennan, Remarks on Discovery, Discovery in Federal Criminal Cases, 33 F.R.D. 56 (1963); Goldstein, The State and the Accused: Balcnce of Advantage in Criminal Procedure, 69 YaLE L.J. 1149 (1960).

330 United States v. Coplon, 185 F.2d 629, 638 (2d Cir. 1950), indicates such a procedure is required. See Westin, Science, Privacy, and Fruedom: Issues and Proposals for the 1970's, 66 Conum. L. Rev. 1205, 1227 (1967). See also Kolod v. Umited States, 36 U.S.L.W. 3306-07 (U.S. Jan. 1968). See generally Pitler, Eavesdropping and Wiretapping-The Aftermath of Katz and Kaiser: A Comment, 35 Broorryn L. Rev. 223 (1968). 


\section{Procedure}

The Supreme Court set out the procedure for determining whether evidence is derived from an illegal source in Nardone $v$. United States: ${ }^{331}$

The burden is, of course, on the accused in the first instance to prove to the trial court's satisfaction that wiretapping was unlawfully employed. Once that is established-as was plainly done here-the trial judge must give opportunity, however closely confined, to the accused to prove that a substantial portion of the case against him was a fruit of the poisonous tree. This leaves ample opportunity to the Governneent to convince the trial court that its proof had an independent origin. $^{332}$

This apparently places the burden on the accused to establish the initial illegality and that a substantial portion of the case against him is a derivative use of the illegal evidence. The prosecution is then given an opportunity to rebut.

In United States v. Coplon, ${ }^{333}$ Judge Learned Hand read Nardone to authorize a procedure whereby the accused carries the initial burden of establishing the primary illegality, but, if he is successful in doing so, "the burden falls upon the prosecution to prove that the information so gained has not 'led,' directly or indirectly, to the discovery of any of the evidence which it introduces." ${ }^{334}$

Sucl a reading appears somewhat strained, ${ }^{335}$ although there is certainly nothing strained about the reasoning advanced in support of such a procedure. In United States v. Goldstein, ${ }^{336}$-decided nearly a decade earlier-Judge Hand analogized the situation to a civil proceeding where "a wrongdoer who has mingled the consequences of lawful and unlawful conduct, has the burden of disentangling them and must bear the prejudice of his failure to do so; that is, that it is unfair to throw upon the innocent party the duty of unravelling the skein which the guilty party has snarled." ${ }^{337} \mathrm{He}$ then completed the analogy:

To impose the duty upon the prosecution is particularly appropriate here, for it necessarily has full knowledge of just how its case has been prepared; given a prima facie case against it, i.e., "taps" and sonie use of them, it should do the rest. ${ }^{338}$

331308 U.S. 338 (1939).

332 Id. at 341.

${ }^{833} 185$ F.2d 629 (2d Cir. 1950).

$334 I d$. at 636 .

335 Judge Hand recognized that he might have misinterpreted Nardone but believed that this test best implemented the purpose of that case. $I d$.

336120 F.2d 485 (2d Cir. 1941).

${ }^{337} I d$. at 488. Judge Hand in Coplon is careful to point out that although the Circuit Court's opinion in Goldstein was affirmed in the Supreme Court, 316 U.S. 114 (1942), that Court was careful not to pass on Hand's interpretation of Nardone. 185 F.2d at 636.

338120 F.2d at 448. 
While the Supreme Court has never passed on Judge Hand's interpretation in the wiretap situation, ${ }^{339}$ it has allocated the burden of proof similarly in dealing with other forms of illegal evidence. In Murphy v. Waterfront Commission, ${ }^{340}$ the defendant refused to testify despite a state grant of immunity, because his answers might have been incriminating under federal law. The Court held that such a refusal was justified and prohibited the Government from making use of any compelled testimony and its fruits. The Court required the defendant to demonstrate "that he has testified, under a state grant of immunity, to matters related to the federal prosecution ...."3341 Once this is done "the federal authorities have the burden of showing that their evidence is not tainted by establishing that they had an independent, legitimate source for the disputed evidence." 342

When a confession is challenged as inadmissible under Miranda the Supreme Court has cast on the prosecution the burden of showing that the required warnings had been given as well as establishing the voluntariness of the waiver ${ }^{343}$ If the prosecution must shoulder the burden of estabhishing the admissibility of the confession, then there appears to be no reason why the defendant should be required to establish the illegality of the confession for the purpose of excluding the fruits.

If the prosecution clainis that the defendant has consented to an otherwise illegal search, then it must establish the voluntariness of the consent. ${ }^{34}$ Thus if the defendant establishes the initial illegality, he must still show some connection between the illegality and the alleged fruit. ${ }^{345}$ If this is done, the burden shifts to the prosecution to establish by clear and convincing evidence that the disputed evidence has been discovered by an independent source. ${ }^{346}$ The failure of the prosecution

339 States in dealing with the problem have placed the burden on the defendant. See, e.g., IrL. Rev. Stat. ch. 38, § 114-12(b) (1965). See also People v. Entrialgo, 19 App. Div. 2d 509, 245 N.Y.S.2d 850 (2d Dept.), $a f^{\prime} d, 14$ N.Y.2d 733, 199 N.E.2d 384, 250 N.Y.S.2d 293 (1963). It appears that if the defendant establishes that the search was without a warrant, then the burden will shift to the government to establish the legality of the scarch. People v. Haven, 59 Cal. 2d 713, 717, 381 P.2d 927, 929, 31 Cal. Rptr. 47, 49 (1963).

340378 U.S. 52 (1964).

341 Id. at 79 n.1.8.

342 Id.

343 Miranda v. Arizona, 384 U.S. 436, 475-76 (1966).

344 Judd v. United States, 190 F.2d 649 (D.C. Cir. 1951); People v. Gorg, 45 Cal. 2d 776, 291 P.2d 469 (1955). See also W. LA FAvE, supra note 83, at 348.

345 Thus in a postindictment lineup context the burden rests on the defendant to establish that counsel was absent from the lineup. After this is done the state must "establish by clear and convincing evidence that the im-court identifications were based upon observations of the suspect other than the lineup identification." United States v. Wade, 388 U.S. 218, 240 (1967).

340 Id. 
to sustain its burden will result in the suppression of the evidence. However, in such a case the indictment need not be dismissed, and the trial can proceed without the introduction of the disputed evidence. ${ }^{347}$

\section{FINAI THOUGHTS}

For those who adhere to the deterrence-causation approach there presently exists at least one shield against the logical radiations of the exclusionary rule that causes much consternation. ${ }^{348}$ The introduction of illegally obtained evidence against a defendant is permissible unless the defendant can estabhish standing to object to the illegal activity. It is especially difficult to accept this proposition in a situation such as People v. Portelli, ${ }^{340}$ where a witness was beaten and burned until he gave information concerning the defendant. It is equally difficult to comprehend a rule which permits pohice to invade homes, wiretap phones, and "bug" bedrooms as long as the information is not used against the owner, or one who is legitimately on the premises or a party to the conversation. ${ }^{350}$

The standing requirement appears to be grounded in a conceptualism about the "personal nature" of the privilege against self-incrimination ${ }^{351}$ in particular and the right of privacy generally. ${ }^{352}$ This may explain the

347 United States v. Blue, 384 U.S. 251 (1966). See Note, Unconstitutionally Obtained Evidence Before the Grand Jury as a Basis for Dismissing the Indictment, 27 MD. L. REv. 168 (1967), where the author concludes that although the exclusion of illegally obtained evidence before the grand jury would be of marginal deterrence, nevertheless such a rule "would be salutory." Id. at 180.

348 See Note, Fruit of the Poisonous Tree-A Plea For Relevant Criteria, 115 U. PA. L. REv. 1136, 1141 (1967); Amsterdam, Search, Seizure, and Section 2255: A Comment, 112 U. PA. L. Rev. 378, 390 (1964).

34915 N.Y.2d 235, 205 N.E.2d 857, 257 N.Y.S.2d 931, cert. denied, 382 U.S. 1009 (1965).

350 For an excellent analysis of the standing requirement in search and seizures see Comment, Standing to Object to an Unreasonable Search and Seizure, 34 U. CHI. L. REv. 342 (1967) and authorities cited at 343 n.8.

351 The privilege against self-incrimination has been traditionally considered to be a right personal to the holder. New York Life Insurance Co. v. People, 195 Ill. 430, 63 N.E. 264 (1902); 8 J. WIGMoRE, supra note 276, $\$$ 2196, 2270. The California supreme court recently adhered to this view in refusing to exclude a weapon found as the result of an accomplice's inadmissible confession. People v. Varnum, 66 Cal.2d 808, 427 P.2d 772, 59 Cal. Rptr. 108 (1967). The court had rejected a standing rule in search and seizure cases in People v. Martin, 45 Cal.2d 755, 290 P.2d 855 (1955).

$352 \mathrm{Mr}$. Justice Frankfurter in Jones v. United States, 362 U.S. 257 (1960), found that the standing requirement rested on "the general principle that a party will not be heard to claim a constitutional protection unless he belongs to the class for whose sake the constitutional protection is given.' [citation omitted] The restrictions upon searches and seizures were obviously designed for protection against official invasion of privacy and the security of property. They are not exclusionary provisions against the adinission of kinds of evidence deemed inherently unreliable or prejudicial." Id. at 261. Therefore, concluded Justice Frankfurter, the rule exists for "the victim of an invasion of privacy." Id.

It is difficult to see how this conclusion follows from the rationale of the exclusionary 
development of the exceptions, but it does not necessarily justify their continued vitality in light of current problems. It is difficult to deny that the standing requirement amounts to a substantial incentive to official illegality and permits the use of evidence significantly connected to that illegality.

Althougl the deterrence-causation rationale appears to underlie the fourth amendment exclusionary rule, some commentators are reluctant to permit even a single conviction to be based on an isolated use of unconstitutionally obtained evidence, even if there exists no need to deter official illegality, ${ }^{363}$ while those opposed to the basic concept of an exclusionary rule maintain the opposite.

These opponents of the exclusionary rule lost two major battles in Mapp and Miranda but now continue the war on new battlefields, warning us of the disastrous effect on law enforcement ${ }^{354}$ - the same argument made in opposition to Miranda - which will result from excluding the fruits of an inadmissible confession.

As we have seen, continued resistance takes several forms. Live witnesses are distinguished from inanimate objects when both are discovered through an initial legality. A confession used as substantive proof of guilt is distinguished from the very same confession used for impeachment purposes. And the inevitable discovery exception looks to swallow the exclusionary rule itself. In these situations, as well as the others discussed herein, the basic contention-that the exclusion of reliable evidence is an undesirable method by which to "police the police"-is resurrected and reasserted. Those who initially supported this contention against any exclusionary rule will be those who now argue for the desirability (if not the necessity) of limiting the scope of the "fruit of the poisonous tree."1365

For the time being, in the context of constitutional and federal violations, the Supreme Court has concluded that deterrence is the rationale and exclusion the remedy. In the context of fifth amendment violations, ample and well-reasoned precedent supports the view that the privilege against self-incrimination, per se, operates to exclude derivative evidence.

rule. If the exclusionary rule is designed to deter illicit police conduct, it would appear that the rule operates prospectively. By excluding evidence of a given illegal search we attempt to prevent this type of activity in the future. Because the rule is designed to protect against future invasions of privacy, to impose a standing requirement militates against the purposes of the rule.

353 See authorities cited note 7 supra.

354 See Lynch, supra note 158.

355 See, e.g., B. George, Constrtutronal Lmamtations on Eividence in Crmuinal Cases (1966); George, "The Potent, The Omnipresent Teacher": The Supreme Court and Wiretapping, 47 Va. L. Rev. 751 (1961). 
This, however, will not inhibit those who seek to construct "shields" in situations they brand "new" and under circumstances they think "compelling." "356

${ }^{85 B}$ The distinctions sought to be drawn are "pure fiction, and fiction always is a poor ground for changing substantial rights." Haddock v. Haddock, 201 U.S. 562, 630 (1906) (Holmes, J., dissenting). 